\title{
La sentencia de la C. S. J. \\ del doce de noviembre de 2014: un tercer momento hito en la evolución de la jurisprudencia sobre la 'dosis personal' para el consumo de estupefacientes
}

El porte de estupefacientes, no solo cuando se trate de "excesos ligeros a la dosis de uso personal", sino también en "cantidad superior a la prefijada por el legislador como dosis personal", no es una conducta antijurídica si se acredita que el agente "indudablemente perseguía satisfacer su propia necesidad de consumo y no finalidades de tráfico", pues tal comportamiento "no tiene la potencialidad de afectar bienes jurídicos ajenos (la salud, la seguridad pública o el orden económico y social)".

César Augusto López Londoño*

\section{The Judgment of the C. S. J. of November 12, 2014: A Third Milestone Moment in the Evolution of Case Law on the 'Personal Dose' for Drug Use}

The possession of drugs, not only in the case of "slight excess dose of personal use", but also in "higher than the preset by the legislature as personal dose amount", is not unlawful conduct if it is established that the agent "undoubtedly pursued the satisfaction of their own consumption and there is no attempt to traffic purposes" because such behavior "has not the potential to affect alien legal rights (health, public safety or the economic and social order)".

\footnotetext{
*Especialista en Derecho Penal.
} 
(Apartes de la sentencia)

\section{CORTE SUPREMA DE JUSTICIA \\ SALA DE CASACIÓN PENAL GUSTAVO ENRIQUE MALO FERNÁNDEZ \\ Magistrado Ponente \\ SP15519-2014 \\ Radicación $\mathrm{N}^{\circ} 42617$. \\ Aprobado acta No. 385.}

Bogotá, D.C., doce (12) de noviembre de dos mil catorce (2014).

\section{I S T OS}

La Corte dicta el fallo mediante el cual decide la demanda de casación instaurada por el Fiscal 48 Seccional de Bello (Antioquia) en contra de la sentencia proferida por el Tribunal Superior de Medellín el 12 de agosto de 2013, mediante la cual confirmó la absolución decretada por el Juzgado Segundo Penal del Circuito de Bello a favor de JOHN HENRY MONTOYA BUSTAMANTE, por el delito de Tráfico, fabricación o porte de estupefacientes.

\section{A N T ECEDENTES}

\section{Fácticos}

En la sentencia impugnada, se enunciaron como hechos penalmente relevantes los siguientes:

El 6 de febrero de 2012, a eso de las 12:38 horas, en una zona boscosa del barrio Paris del Municipio de Bello, específicamente en la carrera 80 con calle 21, agentes de la Policía Nacional que realizaban labores de patrullaje en el sector, cuando se desplazaban a realizar una requisa a dos personas que se encontraban en este lugar, observaron cuando una de ellas, quien posteriormente fue identificado como John Henry Montoya Bustamante, arrojó una bolsa transparente al suelo, y al ser revisada se halló en su interior 52 gramos de marihuana y 0,8 gramos de cocaína.

\section{Procesales}

En audiencias preliminares celebradas el 7 de febrero de 2012 ante el Juzgado Segundo Penal Municipal de Bello (Antioquia), (i) se legalizó la captura de JOHN HENRY MONTOYA BUSTAMANTE, y (ii) se le formuló imputación como presunto autor del delito de Tráfico, fabricación o porte de estupefacientes (verbos: portar o llevar consigo).

Una vez la Fiscalía presentó el escrito de acusación ${ }^{1}$ por el mismo delito que inicialmente imputó, el Juzgado Segundo Penal del Circuito de Bello 
asumió su conocimiento y realizó la audiencia de formulación de acusación y la preparatoria los días 3 y 31 de julio de 2012, respectivamente.

El Juicio Oral se llevó a cabo en dos sesiones: el 16 de octubre y el 21 de noviembre de 2012. En esta última, el juzgado anunció sentido de fallo absolutorio, del cual se hizo lectura en audiencia celebrada el 10 de diciembre de ese mismo año. Contra esa decisión, la Fiscalía interpuso recurso de apelación que sustentó oralmente.

El Tribunal Superior de Medellín resolvió la apelación el 16 de agosto de 2013 confirmando la sentencia absolutoria. A su vez, esta decisión fue objeto del recurso de casación por el delegado de la Fiscalía, quien presentó la respectiva demanda el 6 de septiembre siguiente.

La demanda de casación fue admitida mediante auto del 25 de noviembre de 2013 y la audiencia de sustentación se celebró el 15 de julio de 2014.

\section{LA DEMANDA}

Luego de identificar los sujetos procesales, los hechos juzgados, la actuación procesal relevante y los fundamentos de la sentencia impugnada, manifestó que esta última afectó derechos o garantías fundamentales (salud pública) por violación directa de la ley sustancial (art. 181-1 C.P.P./2004) en la modalidad de interpretación errónea del artículo 11 del Código Penal.

En primer lugar, trae a colación la sentencia SU-047 de 1999 para advertir sobre la obligatoriedad del precedente judicial en Colombia. Luego, cita y trascribe parcialmente sentencias dictadas por esta Corporación en relación al valor de la jurisprudencia como fuente de derecho: 1) la del 16 de septiembre de 2010, Rad. 26680; 2) la del 1 de febrero de 2012, Rad. 34853; 3) la del 14 de noviembre de 2012, Rad. 34015; y 4) la del 21 de noviembre de 2012, Rad. 39858.

Una vez realiza tales precisiones, se pregunta si existió un cambio de perspectiva jurisprudencial debido a las disposiciones contenidas en el Acto Legislativo No 002 de 2009, tal y como lo afirmó el Tribunal Superior de Medellín. Luego, estima errado que este último manifieste que a partir de la reforma constitucional se inhibe al Estado de perseguir penalmente al consumidor, aun cuando a renglón seguido reconozca "que en tanto se porte el estupefaciente para ese fin y en cantidad que no obligue a descartar ese propósito", pues bajo tal entendimiento aquél siempre resultaría impune al porte y a la conservación de las sustancias ilícitas.

Señala que muy a pesar que en la sentencia se admite que más allá de la prueba de la condición de adicto es la cantidad hallada en su poder la que obliga a confirmar o descartar el propósito del consumo; también aseguró alejándose del precedente jurisprudencial, que el nuevo marco normativo obligaba a replantear el concepto de dosis de aprovisionamiento y, lo que considera más grave aún, que en la sentencia C-491 de 2012 se avaló "la 
ausencia de punición de la dosis personal de estupefacientes, así como la sanción de cantidades menores destinadas al tráfico", tesis según la cual ahora estaría permitido el microtráfico de estupefacientes.

Advierte el demandante que la misma Corte Constitucional en dicha sentencia reconoció que la Sala de Casación Penal ha desarrollado un precedente en materia de tratamiento político-criminal del porte de dosis personal de sustancia estupefaciente, el cual se encuentra consignado fundamentalmente en las sentencias proferidas en los procesos 23609 de 2007, 28195 de 2008, 31531 de 2009 y 35978 de 2011, y se desarrolló a través de cinco reglas². En este contexto concluye que "..., la prohibición del artículo 49 de la Constitución, no ampara la penalización del porte y consumo de estupefaciente en dosis mínima."

Insiste en que el asunto de las cantidades que ligeramente sobrepasan lo dispuesto por la ley como dosis para el consumo personal, continúan su desarrollo en la sentencia del 17 de agosto de 2011, Rad. 35978, que examinó los efectos del Acto Legislativo No 002 de 2009, la cual cita en extenso para advertir que antes y después de esta reforma, es posible no sancionar penalmente al consumidor que es sorprendido en posesión de estupefacientes en las cantidades definidas en la ley o las que ligeramente las superen, siempre y cuando se demuestre esa destinación.

En el caso concreto, continúa, el defensor probó la condición de adicto a la marihuana del procesado; sin embargo, estima el impugnante que ese argumento no puede disculpar la conducta investigada según la cual aquél portaba marihuana en una cantidad superior a dos veces la dosis tolerada (52 gramos), pues claramente esa cuantía desborda los límites de razonabilidad y tal evento permite presumir una destinación ilícita de la droga incautada con peligro para el bien jurídico de la salud pública.

Por último, advierte que la tesis del Tribunal Superior de Medellín implica que los adictos por su sola condición, no solo deben ser impunes a las conductas de portar o conservar estupefaciente, sino también a la de comprar o adquirir. En virtud de lo anterior, solicita se case la sentencia para que, en su lugar, se condene al procesado como autor material del delito de Tráfico, fabricación o porte de estupefacientes, en la modalidad de llevar consigo.

\section{AUDIENCIA DE SUSTENTACIÓN}

En la audiencia, la delegada de la Fiscalía manifestó que estaba conforme con los argumentos de la demanda, mientras que el defensor solicitó no casar la sentencia impugnada y, en su lugar, sea confirmada, pues no se estructura el cargo.

\section{O N S I D E R A C I O N E S}

El delegado de la Fiscalía General de la Nación fundó su demanda de casación en la presunta violación directa de la ley sustancial, toda vez que 
por una interpretación errónea del artículo 11 del Código Penal y de la línea jurisprudencial vigente en relación a la antijuridicidad en el delito de Tráfico, fabricación y porte de estupefacientes, especialmente lo relativo a la conducta de llevar consigo para el consumo, decidió absolver a JHON HENRY MONTOYA BUSTAMANTE cuando el entendimiento adecuado de tales parámetros normativos debió derivar en la condena.

\title{
1. Consideraciones preliminares acerca del delito de "Tráfico, fabricación y porte de estupefacientes"
}

\begin{abstract}
«Artículo 376. Modificado. L. 1453/2011, art. 11. Tráfico, fabricación o porte de estupefacientes. El que sin permiso de autoridad competente, introduzca al país, así sea en tránsito o saque de él, transporte, lleve consigo, almacene, conserve, elabore, venda, ofrezca, adquiera, financie o suministre a cualquier título sustancia estupefaciente, sicotrópica o drogas sintéticas que se encuentren contempladas en los cuadros uno, dos, tres y cuatro del Convenio de las Naciones Unidas sobre Sustancias Sicotrópicas, incurrirá en prisión de ciento veintiocho (128) a trescientos sesenta (360) meses y multa de mil trescientos treinta y cuatro (1.334) a cincuenta mil (50.000) salarios mínimos legales mensuales vigentes.
\end{abstract}

Si la cantidad de droga no excede de mil (1.000) gramos de marihuana, doscientos (200) gramos de hachís, cien (100) gramos de cocaína o de sustancia estupefaciente a base de cocaína o veinte (20) gramos de derivados de la amapola, doscientos (200) gramos de droga sintética, sesenta (60) gramos de nitrato de amilo, sesenta (60) gramos de ketamina y GHB, la pena será de sesenta y cuatro (64) a ciento ocho (108) meses de prisión y multa de dos (2) a ciento cincuenta (150) salarios mínimos legales mensuales vigentes.

Si la cantidad de droga excede los límites máximos previstos en el inciso anterior sin pasar de diez mil (10.000) gramos de marihuana, tres mil (3.000) gramos de hachís, dos mil (2.000) gramos de cocaína o de sustancia estupefaciente a base de cocaína o sesenta (60) gramos de derivados de la amapola, cuatro mil (4.000) gramos de droga sintética, quinientos (500) gramos de nitrato de amilo, quinientos (500) gramos de ketamina y GHB, la pena será de noventa y seis (96) a ciento cuarenta y cuatro (144) meses de prisión y multa de ciento veinticuatro (124) a mil quinientos (1.500) salarios mínimos legales mensuales vigentes».

Como puede observarse, el tipo penal transcrito es compuesto o alternativo porque prohíbe un número plural de conductas (introducir al país, sacar de él, transportar, llevar consigo, almacenar, conservar, elaborar, vender, ofrecer, adquirir, financiar o suministrar), cada una de las cuales de manera autónoma puede configurar el delito de Tráfico, fabricación y porte de estupefacientes. Ante tal situación, se advierte desde ya que el presente análisis versará exclusivamente sobre la conducta de portar o llevar consigo sustancias estupefacientes o sicotrópicas, pues es esta la conducta concreta por la que se investigó y juzgó al procesado, especialmente cuando el destino de tales drogas es el consumo personal.

Otro comentario inicial que es posible hacer a partir de la sola redacción del tipo penal en cuestión, es que en la conducta consistente en portar o 
llevar consigo estupefacientes para el propio consumo, el factor cuantitativo juega varios roles: 1) Es un elemento determinante de tipicidad, pues solo un exceso de la dosis personal establecida en el artículo 2, literal j), de la Ley 30 de 1986, permite ubicar el comportamiento en el espectro típico; 2) En consecuencia, la cantidad de droga es uno de los elementos típicos a partir del cual se presume la existencia de riesgo para los bienes jurídicos protegidos; y 3) Es criterio de graduación de la punibilidad, al igual que para las demás conductas prohibidas en el tipo, pues la pena imponible será mayor en la medida en que también lo sea la cantidad de estupefacientes que constituya el objeto material del delito.

Por último, debe advertirse que la exequibilidad de la prohibición típica del porte de estupefacientes en cantidad que exceda la dosis legal de uso personal, independiente de que su finalidad sea el tráfico o el consumo; ha sido avalada directa o indirectamente en sede de control de constitucionalidad, en la sentencias C-221 de 1994 y la C-491 de 2012. Por ende, las consideraciones que se expondrán se referirán al ámbito de la antijuridicidad, además porque el debate planteado por la demanda de casación gira en torno a la lesividad de la conducta de llevar consigo estupefaciente para el uso personal.

\section{Jurisprudencia penal sobre el porte de estupefacientes para el consumo personal}

En providencia del 8 de agosto de 2005, Rad. 18609, con fundamento en los principios de lesividad y de intervención mínima (fragmentariedad, última ratio y subsidiariedad), la Sala consideró que "... las cantidades que se acercan al límite de lo permitido para consumidores, se ubica en una sutil franja de lo importante a lo insignificante. Empero, si bien el legislador no le ha otorgado discrecionalidad al juez para modificar las cantidades en orden a su punibilidad, debe tenerse en cuenta que lo dispuesto para la dosis personal marca una pauta importante para fijar la ponderación del bien jurídico en orden a su protección". En esa ocasión, se examinó la punibilidad de una conducta consistente en portar para el consumo una cantidad de 1.24 gramos de cocaína, cuando lo permitido para tal fin es de 1 gramo. De manera contundente se afirmó que "resultaría sofístico afirmar que los 0.24 gramos convierten al consumidor en portador punible, potencialmente expendedor, deja de ser consumidor.".

Luego, en el auto del 8 de octubre de 2008, Rad. 28195, se reiteró que el porte de estupefacientes en cantidad que no supere de manera excesiva la dosis mínima, "carecerá desde el punto de vista objetivo de relevancia penal según lo estipulado en el artículo 11 de la ley 599 de 2000 (principio de antijuridicidad material), siempre y cuando se haya demostrado que sólo podía repercutir en el ámbito de la privacidad de quien la consume. Pero si la conducta atañe a la venta, distribución, tráfico o cualquier otro comportamiento relacionado con el ánimo de lucro del sujeto activo, será punible en la medida en que representa una efectiva puesta en peligro de los bienes e intereses de orden colectivo que el Estado pretende tutelar. En el proceso que se examinó, la Sala estimó 
que la conducta del sujeto que portaba 38.7 gramos de marihuana, era antijurídica porque la finalidad de esa tenencia era el expendio o la distribución.

Poco tiempo después, el 18 de noviembre de 2008, en el proceso radicado con el No 29183 se absolvió al enjuiciado porque se consideró que los 29.9 gramos de marihuana que tenía en su poder constituían un exceso ligero de la dosis personal y estaban destinados a su propio consumo. En esa ocasión se expusieron las siguientes premisas: 1) Que el delito de Tráfico, fabricación y porte de estupefacientes (art. 376 C.P.) es de peligro abstracto; 2) Que el concepto de dosis personal permite diferenciar si el agente tiene la sustancia para su propio consumo, o si la situación en que se encuentra involucra o insinúa el tráfico de drogas; 3) Que la antijuridicidad de la conducta del consumidor depende de que trascienda su fuero interno y llegue a afectar derechos ajenos; $y, 4)$ Se exhortó a jueces y fiscales para que, en desarrollo del alcance del Estado social y democrático, se discriminara positivamente a las personas que como los consumidores requieren de atención diferente a la pena.

En proveído del 8 de julio de 2009, Rad. 31531, la Corte absolvió al procesado por la conducta de llevar consigo 1.3 gramos de cocaína para su consumo, luego de reconocer que 1) el uso de sustancias estupefacientes y psicotrópicas genera problemas de adicción que convierten a la persona "en un enfermo compulsivo (en variedad de intensidades) merecedor de recibir tratamientos médicos terapéuticos antes que un castigo, pena o reducción a un establecimiento carcelario."; y que 2) en tales condiciones de afectación psicofísica, cuando detecta una fuente de abastecimiento opta muchas veces por adquirir cantidades "un poco mayores a las permitidas" que le sirvan para el consumo no en una sino en varias oportunidades (dosis de aprovisionamiento); conducta esta que no representa ni siquiera un peligro para el bien jurídico.

Además, en la providencia se citaron fuentes doctrinales y se invocaron argumentos propios de la Sala que respaldan la ausencia de lesividad en el consumo de estupefacientes y en la tenencia para tal fin exclusivo, así:

"Hay que poner de manifiesto que en el Código penal de 1995 (se refiere al estatuto español), se sigue despenalizando la posesión de estupefacientes encaminada al consumo, sin exigir legalmente ninguna condición de indole cuantitativa (v. gr. que se trate de módicas cantidades etc.), o de indole temporal (v. gr. que las cantidades poseídas no superen las necesidades de consumo de una semana, etc.), lo que a mi parecer, es digno de todo elogio, pues semejantes límites o condiciones no hace más que crear un sistema de presunciones absolutas "musir et de iure" de destino al tráfico de la sustancia cuando no se cumplen los requisitos legales, no prestando atención entonces a la intención del sujeto, que es lo que en todo caso debe prevalecer, dando lugar a un Derecho penal de mera sospecha que entra en abierta contradicción con el principio de culpabilidad que debe imperar en todo Estado democrático de derecho" 3 .

El principio de lesividad encuentra correspondencia en el postulado del harm principle:

"El énfasis en la lesión de los intereses de terceros, central para el harm principle, puede contribuir a demarcar la diferencia entre el menoscabo de los intereses de terceros y 
los intereses del propio agente, diferencia también reconocida dentro de la teoría del bien jurídico aunque no suficientemente atendida. Ello puede mostrarse de la mano de la discusión sobre la penalización del consumo de drogas (...) No hay duda de que hay ciertas drogas nocivas para la salud, al menos para la salud de aquellos que las consumen. Es decir, los daños para la salud resultantes de consumo de drogas son auto infligidos por los consumidores. $Y$ los daños que uno mismo se inflige tienen poco o nada que ver con el menoscabo de intereses de terceros. Es indudable que tengo un interés jurídicamente merecedor de protección en que mi salud no sea menoscabada por acciones de tercero. Pero, ¿tengo una pretensión semejante hacia mí mismo? La idea de la amenaza de un bien propio resulta forzada. Si se quiere sostener la legitimación de los tipos penales del derecho penal de las drogas en un bien jurídico vinculado a la salud, debería configurarse este de modo que sólo quedarían abarcados daños a la salud causados por terceras personas, lo que sin embargo vendría a restringir de modo considerable el ámbito de aplicación de dichos tipos legales, los cuales, no obstante, sólo a través de esa vía serían susceptibles de legitimación. En todo caso, desde esa perspectiva no puede justificarse la reacción penal frente al consumo voluntario de drogas" ${ }^{\prime 4}$.

El 17 de agosto de 2011, Rad. 35978, en posición que fue citada luego el 18 de abril de 2012, Rad. 38516, se reiteró la ausencia de lesividad de conductas de porte de estupefacientes encaminadas al consumo dentro de los límites de la dosis personal, pues estas no trascienden a la afectación, siquiera abstracta, del bien jurídico de la salud pública. Sin embargo, en la primera ocasión también se advirtió que aún con las modificaciones introducidas por el Acto Legislativo No 02 de 2009 y el artículo 11 de la Ley 1453 de 2011, "es posible tener por impunes las conductas de los individuos dirigidas al consumo de estupefacientes en las dosis fijadas en el literal j) del artículo $2^{\circ}$ de la Ley 30 de 1986, o en cantidades ligeramente superiores a esos topes,...". De igual forma, se dedicaron algunas líneas a los fundamentos que legitiman la punición del delito de Fabricación, tráfico y porte de estupefacientes, entre los cuales se resaltan los que determinan un tratamiento diferencial para el consumidor:

Es claro cómo la prohibición del artículo 49 superior se ve materializada y encuentra su desarrollo en la sanción penal para todo tipo de porte de sustancias alucinógenas prohibidas, sin distinción de si su destino es para el propio consumo o para el tráfico y distribución. Aceptar dicha conclusión sería tanto como avalar un procedimiento de carácter sancionatorio para el enfermo que padece de adicción a sustancias alucinógenas, y por vía de la pena, el Estado exigirle al individuo el cuidado de su propia salud, privándolo de su derecho a la libertad de locomoción cuando ha decidido abandonar la preservación de su salud física y mental, optando por el consumo de drogas. (...). No puede pasarse por alto que la sanción penal contenida en los artículos 376 y siguientes de dicho estatuto, es producto del compromiso adquirido por Colombia a través de la Convención de las Naciones Unidas contra el Tráfico Ilícito de Estupefacientes y Sustancias Sicotrópicas aprobada mediante Ley 67 de agosto 23 de 1993, cuyo proceso de revisión constitucional se hizo en sentencia C-176 de 1994, la cual impone a los Estados parte, la tipificación de comportamientos que tengan que ver con el comercio de estas sustancias, siendo esta su principal finalidad, más no la sanción para el consumidor, pues dicha cuestión se dejó a reserva de cada Estado de acuerdo con sus principios constitucionales ${ }^{5}$, siendo lo que se ajusta a nuestro orden interno, aquella posición que propende por la no sanción del porte de sustancias por parte del adicto para su consumo en las cantidades fijadas por nuestro legislador, 
postura sentada desde el año 1994 en la tantas veces mencionada sentencia C 221. (...). También cómo la orientación del legislador interno y de la comunidad internacional, no se dirige hacia el ataque y criminalización del consumidor, sino hacia la neutralización de conductas que trascienden la esfera individual, para constituirse en un verdadero peligro para la comunidad que de ninguna manera pueden ser toleradas.

No obstante, al analizar el caso concreto en el cual se había enjuiciado y condenado a un individuo porque portaba 79.9 gramos de marihuana, la Sala determinó que a pesar que no se había acreditado la finalidad de la distribución onerosa o gratuita de la sustancia, la sola cantidad, al superar casi en 4 veces el tope legal permitido, hacía presumir la puesta en riesgo de bienes jurídicos como la salud pública, el orden económico y social, entre otros intereses o, en otras palabras, "..., no es posible concluir que esté destinada al consumo, sino a cualquiera de las conductas consideradas lesivas y por tanto, objeto de sanción penal.".

Hace muy poco, en sentencia de casación del 3 de septiembre de 2014, Rad. 33409, la Corte reiteró la posición según la cual la posesión de cantidades ligeramente superiores a la dosis personal legal no alcanza a lesionar los bienes jurídicos tutelados, por lo que no genera responsabilidad penal. Además, de manera expresa se reconoció que tal tesis ya constituía una línea jurisprudencial pacífica. Sin embargo, en el caso puntual en que el procesado fue capturado cuando portaba 2.2 gramos de cocaína y 51.8 gramos de marihuana, se consideró que la conducta era antijurídica porque ningún medio de conocimiento allegó la defensa para acreditar la condición de adicto de aquél ni su finalidad de consumo ${ }^{6}$.

\section{Conclusión provisional.}

La posición uniforme de la Corte en relación al porte de estupefacientes destinado al consumo se puede sintetizar así: si la cantidad que se lleva consigo sobrepasa ligeramente la dosis legal de uso personal carecerá de lesividad por su insignificancia. Un exceso superior, aun cuando sea para el propio consumo, siempre será antijurídico porque hace presumir -de derecho- el riesgo para la salud pública, el orden socioeconómico y la seguridad pública, tal y como se afirmó en la decisión proferida el 17 de agosto de 2011, Rad. 35978. En ese orden, se tendría que cuando el exceso es mínimo la presunción de antijuridicidad es iuris tantum porque admite prueba en contrario, como la del fin de consumo, mientras que cuando el exceso es mayor la presunción es iuris et de iure porque no admite controversia probatoria alguna.

En esta ocasión se considera que la tesis principal que se ha erigido en línea jurisprudencial debe revisarse por cuatro razones fundamentales:

1) Porque, como se vio, en muchas de las decisiones de esta Corte ya se contemplan argumentos constitucionales, doctrinales y de derecho comparado, que permiten vislumbrar la falta de lesividad del porte de estupefacientes para el consumo. 
2) Porque prohíja una doble naturaleza de la presunción de antijuridicidad en que se fundan los delitos de peligro abstracto: es iuris tantum para los eventos de exceso mínimo de la dosis personal y es iuris et de iure para las demás hipótesis, sin que exista una razón válida para una tal distinción generalizada y, además, es inconsecuente con la jurisprudencia que sobre ese punto se ha sostenido.

3) Porque a partir del Acto Legislativo No 02 de 2009 se erigió al consumidor de sustancias estupefacientes y psicotrópicas, especialmente al adicto, como sujeto de protección constitucional reforzada, lo cual impide que la misma condición que le hace merecedor de una discriminación positiva, a la vez, pueda constituir el contenido de injusticia de un delito. Y,

4) Porque la tendencia contemporánea hacia la despenalización de las conductas de porte y conservación relacionadas con el consumo de drogas, la cual predomina en distintos sectores de los gobiernos locales, de los organismos internacionales, de la academia y de la sociedad en general; obliga a la judicatura a una reflexión permanente, por lo menos, en lo que hace a efectiva antijuridicidad de tales comportamientos.

\section{Delitos de peligro abstracto: la presunción del riesgo es iuris tantum}

Tanto la jurisprudencia constitucional como la ordinaria tienen definido que el delito de Tráfico, fabricación y porte de estupefacientes, puede afectar no sólo el bien jurídico de la salud pública sino otros como el orden económico y social y la seguridad pública ${ }^{7}$. Además, desde el punto de vista del grado de afectación que a tales intereses puede causar dicha conducta punible, la misma se ha clasificado como "de peligro" por cuanto la mayoría de las veces no supone una lesión efectiva sino sólo un riesgo para la incolumidad de aquellos. Ahora bien, recuérdese que según la mayor o menor proximidad a la producción de un daño, los delitos de peligro se han subclasificado, respectivamente, en (i) de peligro concreto, demostrable o directo, y (ii) de peligro abstracto, presunto o indirecto.

En todo caso, la pluralidad y la diversidad tanto de conductas que se prohíben en el artículo 376 del Código Penal que, por lo menos, se reconducen a 3 categorías distintas (Tráfico, Fabricación o Porte), como de los bienes jurídicos que con tales restricciones se busca proteger; obligan a un examen particularizado en cuanto a la naturaleza de la afectación que cada una de aquéllas representa para los variopintos intereses tutelados. Así, por ejemplo, las conductas de fabricación y tráfico de estupefacientes pueden suponer una lesión efectiva a la economía nacional y un riesgo muy próximo (concreto, directo, demostrable) a la salud pública. Mientras que, la sola tenencia de drogas especialmente aquella destinada no al tráfico sino al consumo personal, a lo sumo puede significar un peligro abstracto, presunto o indirecto para tales bienes.

Pues bien, el presente análisis se circunscribirá a la antijuridicidad del porte de estupefacientes destinado al consumo personal, pues es este (sic) 
el punto más problemático hoy día en la penalización del narcotráfico, no sólo en nuestro país sino a nivel internacional, como ya se vio en el acápite anterior. Específicamente, habrá de determinarse si la presunción de peligro que configura la lesividad de la tenencia de estupefacientes es de aquellas iuris et de iure por venir prefijada por el legislador, caso en el cual la verificación de la tipicidad de la conducta apareja, automáticamente, su antijuridicidad. O si, por el contrario, dicha presunción es iuris tantum y, por tanto, siempre serían admisibles pruebas que la desvirtúen.

La trascendencia del asunto es tal que de concluirse que la presunción de lesividad es de derecho, en el porte de estupefacientes en cuantía que exceda las dosis establecidas en el artículo 2, literal j), de la Ley 30 de 1986, aun cuando su destino exclusivo sea el consumo personal; inexorablemente la tipicidad acarreará la antijuridicidad. Mientras que, si la conclusión es la opuesta, es decir, que la presunción es legal, la conducta será típica pero la demostración de que no existió interferencia ni siquiera remota en los derechos de terceros, sean éstos individuales o colectivos, excluye la dañosidad del comportamiento y, por ende, la responsabilidad penal.

En relación al problema jurídico planteado, dos han sido las posiciones históricas de la Corte. Según la primera, en los delitos de peligro abstracto la presunción de antijuridicidad de la conducta es iuris et de iure, criterio este que se sostuvo principalmente al amparo de la Constitución de 1886 y del Código Penal de 1980 (art. 4) $)^{8}$ Y, en la segunda, se ha considerado que la naturaleza de la presunción es iuris tantum, la cual resulta más acorde con el espíritu de

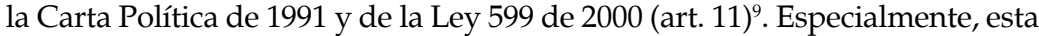
última disposición normativa introdujo una modificación sustancial en la categoría de la antijuridicidad cuando exigió de manera expresa que la lesión o la puesta en peligro del bien jurídico tutelado fuese efectiva.

(i) La tesis inicial puede encontrarse en decisiones como el fallo del 22 de septiembre de 1982 y el auto del 25 de marzo de 1998, Rad. 13141.

En la providencia de 1982, la Corte, luego de precisar las dos modalidades de los delitos de peligro y las diferentes denominaciones que las mismas han recibido, define las implicaciones que una y otra conllevan en sede de la demostración de la antijuridicidad. Veamos:

Con todo, puede afirmarse que existen dos clases de delitos de peligro, cuya diferencia obedece a la proximidad y gravedad del riesgo respecto al bien jurídico tutelado y que unos autores llaman de "peligro abstracto" y "de peligro concreto", denominaciones que otros califican de impropias, porque, como dice alguno de los últimos, "el peligro es siempre una abstracción", motivo por el cual prefieren calificarlos de "peligro directo" y "peligro indirecto", para indicar que el riesgo en los primeros amenaza en forma inmediata el bien y en los segundos, sólo de modo indirecto.

Más importancia tiene la que los dividen en delitos "de peligro presunto" y "de peligro demostrable", porque en los primeros la ley presume de modo absoluto la posibilidad de un daño para el bien jurídicamente tutelado y no 
sólo no requieren, sino que, por el contrario, excluyen cualquier indagación sobre si se da o no la probabilidad del perjuicio o lesión de este.

En tanto que los otros requieran que se demuestre la posibilidad de daño, es decir, comprobación de que hay un peligro.

Estos últimos se conocen porque el texto de la ley contiene, en forma expresa o tácita, las exigencias de esa demostración.

Implica esta distinción la consecuencia de que en los delitos de peligro presunto una determinada situación subsumible en la respectiva descripción legal, debe ser sancionada aun cuando no haya determinado el peligro que constituye la razón de la norma.

Luego, el auto del 25 de marzo de 1998 que reprodujo parcialmente el fallo del 22 de septiembre de 1982, se concluyó que ninguna polémica debía generar la consideración de una irremediable antijuridicidad presunta. Así se manifestó en esa oportunidad:

$Y$, pese a reconocerse que en la doctrina son múltiples las discrepancias en torno a la clasificación de los delitos por razón del bien jurídico tutelado respecto de su efectiva o potencial vulneración, polémica ninguna amerita el hecho de que si la descripción de la conducta per se no exige una efectiva o concreta amenaza, basta con que ella sea abstracta o presunta por ministerio de la ley, para que en esos casos pueda recaer un juicio de desvalor.

(ii) La segunda tesis se ha materializado, principalmente, en las providencias del 15 de septiembre de 2004, Rad. 21064, y del 12 de octubre de 2006, Rad. 25465.

La primera decisión resulta de gran trascendencia porque abordó el estudio del fondo de una demanda de casación que se había admitido con el propósito expreso de desarrollar jurisprudencia en torno a la aplicación del principio de lesividad en los delitos de peligro abstracto y al alcance de la efectiva creación de riesgos que exigía el artículo 11 de la Ley 599 de $2000^{10}$. Bajo ese entendido se concluyó que la presunción de peligro en los delitos que adoptaran tal configuración legal no podía ser iuris et de iure porque ello supondría un desconocimiento del carácter social y democrático de nuestro Estado de derecho que se funda, esencialmente, en la dignidad humana, así como una vulneración de garantías constitucionales fundamentales como son la presunción de inocencia, la defensa y la contradicción. Por ende, "frente a un delito de peligro debe partirse de la base de que la presunción contenida en la respectiva norma es iuris tantum, es decir, que se admite prueba en contrario acerca de la potencialidad de la conducta para crear un riesgo efectivo al bien jurídico objeto de tutela.".

Las premisas de tal conclusión fueron las siguientes:

1. Es legítima la consagración legislativa de delitos de peligro abstracto como lo dejó entrever la Corte Constitucional en la sentencia C-430 del 12 de 
septiembre de 1996; sin embargo, en ese mismo precedente se advirtió que: "Cuando el peligro es remoto, el bien no se halla amenazado en forma concreta, y lo que en realidad se castiga es la mera desobediencia o violación formal de la ley con la realización de una acción inocua en si (sic) misma"; por ende, en la determinación de una relación de causalidad entre la conducta típica y la amenaza o daño al bien jurídico, concurren el legislador cuando realiza una selección anticipada de prohibiciones y el juez que analiza y valora el caso concreto ${ }^{11}$.

2. Entonces, si bien el legislador es el competente para seleccionar las conductas que estima indeseables con tan solo generar riesgos a los intereses jurídicos tutelados, es decir, establece anticipadamente una presunción de peligro; es al juez al que le atañe verificar que un específico comportamiento representó la efectiva creación de ese peligro. Así, se advierte que no se pueden confundir la órbita de la abstracta libertad de configuración del legislador con la de la concreta valoración judicial de la relevancia social de una conducta.

3. El derogado artículo 4 del Decreto-Ley 0100 de 1980 que definía la antijuridicidad, no preveía ningún requerimiento en relación al grado de afectación a los intereses que se protegían. En ese orden, "... con abstracción de los valores que respecto de la dignidad humana y el respeto a los derechos fundamentales se desprenden de la Constitución, podía aducirse que en relación con los delitos de peligro abstracto o indirecto, como también los conoce la doctrina, nada diferente importaba a constatar la conducta supuestamente generadora de riesgo".

4. Por el contrario, la previsión del artículo 11 de la Ley 599 de 2000, al exigir la efectiva lesión o puesta en peligro del bien jurídico, "armoniza la necesidad abstracta de protección satisfecha con la creación del tipo penal y la garantía de protección al justiciable, bajo el entendido que su conducta sólo será punible en cuanto con ella cree situaciones de riesgo inadmisibles, efectivas, al señalado interés".

5. Ese antecedente consignado en las providencias del 22 de septiembre de 1982 y del 25 de marzo de 1998, Rad. 13141, expresamente se consideró inaplicable en el marco jurídico de la Constitución de 1991 y del Código Penal de 2000, porque "respondía a una sistemática interpretativa diferente basada en puros criterios intrasistemáticos, sin referencia al orden constitucional imperante, el de la Carta de 1886 y que, por consiguiente, no repelía el juzgamiento de delitos sin daño o sin creación o incremento efectivo de peligro.".

En la sentencia del 12 de octubre de 2006, Rad. 25465, la Sala reiteró que la presunción en los delitos de peligro abstracto admitía prueba en contrario y para tal efecto citó un argumento adicional de mucha solidez. En efecto, se adujo que en la exposición de motivos del entonces proyecto de ley se explicó que la incorporación del término "efectivamente" en la definición de la antijuridicidad obedecía a la necesidad de "abandonar la llamada presunción iuris et de iure de peligro consagrada en algunos tipos penales.". En fin, se manifestó que: 
(...), contrario a lo expuesto por la doctrina tradicional que entendía que en los delitos de peligro presunto se suponía de derecho la antijuridicidad de la conducta, lo cierto es que ahora, respecto de tales comportamientos no basta con realizar simple y llanamente el proceso de adecuación típica de la conducta para luego dar por presupuesta su antijuridicidad, pues siempre se impone verificar si en el caso concreto tal presunción legal es desvirtuada por alguna prueba en contrario, dado que de ser ello así, el comportamiento no deviene antijurídico y sin tal categoría dogmática, la conducta no configuraría delito.

Por último, es de resaltar que con posterioridad, la Corte Constitucional en sentencia C-491 de 2012 mediante la cual analizó la exequibilidad del artículo 376 del Código Penal modificado por la Ley 1453 de 2011, acogió la tesis según la cual la dosis personal para el consumo es una presunción legal (iuris tantum) y como tal admitiría prueba en contrario la antijuridicidad de una conducta de porte que exceda el límite cuantitativo prefijado por el legislador. Así lo manifestó la jurisprudencia constitucional:

Es preciso aclarar que la dosis personal es un concepto objetivo que hace referencia a la cantidad de sustancia estupefaciente que, de conformidad con una presunción legal, es la que resulta compatible con el consumo personal, y por ende no está destinada a la comercialización o distribución. (...).

\section{Conclusión provisional.}

La interpretación histórica, sistemática, exegética, pero sobre todo la de carácter constitucional que realizó la Corte en las providencias que se acaban de citar, permite afirmar que la legitimidad de la facultad del legislador para configurar delitos de peligro abstracto, especialmente hoy por el nivel exagerado de riesgo en las sociedades modernas, no conlleva que la presunción de antijuridicidad en que se fundan sea iuris et de iure; por el contrario, necesariamente el concepto actual de la antijuridicidad como efectiva lesión o puesta en peligro de bienes protegidos, implica que la presunción de estas afectaciones pueda ser revisada e inclusive desvirtuada por la judicatura en los casos que se sometan a su conocimiento (iuris tantum).

\section{Marco constitucional del porte de estupefacientes para el consumo personal}

\subsection{Antes del Acto Legislativo No 02 de 2009.}

La Convención de Viena impuso a los Estados partes (sic) la obligación incondicional de tipificar las conductas que directa o indirectamente configuraran el fenómeno de tráfico ilícito de estupefacientes, tales como son: la producción, la fabricación, la oferta, la venta, la distribución, el envío, el transporte, la importación o la exportación. En cuanto al consumo personal de estupefacientes, su tipificación sólo se consideró imperativa cuando ello se correspondiera con los principios constitucionales y con los conceptos jurídicos fundamentales del Estado. Así lo consideró la Corte Constitucional en la sentencia C-176 de 1994 mediante la cual se estudió 
la exequibilidad de la Ley 67 de 1993 por medio de la cual se aprobó dicho tratado internacional.

Posteriormente, en la sentencia C-221 de 1994 se estableció que la penalización del consumo de la dosis para uso personal contemplada en el artículo 51 de la Ley 30 de 1986 (llevar consigo, conservar para su propio uso o consumir), vulneraba la dignidad humana y el libre desarrollo de la personalidad, razón por la cual esa disposición normativa se declaró inexequible. Sin embargo, consideró ajustada a la Carta Política la determinación legislativa de la dosis para consumo personal, toda vez que fija los límites de una actividad lícita frente a la ilícita del narcotráfico que, en función de lucro, estimula tendencias socialmente indeseables. La conclusión de inexequibilidad partió de las siguientes premisas básicas:

1) El consumo personal de sustancias estupefacientes es una "conducta que, en sí misma, sólo incumbe a quien la observa y, en consecuencia, está sustraída a la forma de control normativo que llamamos derecho y más aún a un sistema jurídico respetuoso de la libertad y de la dignidad humana, como sin duda, lo es el nuestro".

2) La prohibición y sanción punitiva del consumo de la dosis personal vulnera la dignidad humana al desconocer la condición de sujeto ético del consumidor, pues lo releva de la decisión de asuntos en ámbitos que solo a él atañen. Asimismo, desconoce el libre desarrollo de la personalidad al regular, prohibiendo y sancionando, una conducta que no interfiere en los derechos de los demás.

3) Un Estado respetuoso de la dignidad humana, de la autonomía personal y del libre desarrollo de la personalidad, no puede renunciar a la obligación de educar para prevenir conductas que considere indeseables, reemplazándola por la represión como forma de controlar el consumo de sustancias que se juzgan nocivas para la persona $y$, eventualmente, para la comunidad.

4) A semejanza de lo que ocurre con el alcohol y el tabaco, el Estado puede regular mediante normas policivas las circunstancias de lugar, de edad, de ejercicio temporal de actividades y otras análogas, dentro de las cuales el consumo de drogas resulte inadecuado o socialmente nocivo, sin que en todo caso se desconozca el núcleo esencial de los derechos a la libertad y a la igualdad.

Por último, tanto en la sentencia C-221 de 1994 como en la C-420 y en la C-689, ambas de 2002, en torno a la legitimidad de la punición de las conductas relacionadas con el narcotráfico, se advirtió que "debía distinguirse entre el porte, conservación o consumo de sustancias estupefacientes en cantidad considerada como dosis de uso personal y el narcotráfico como actividad ilícita alentada por el afán de lucro pues los efectos del fallo únicamente se extendían a aquella actividad y no a esta". Obsérvese que la delimitación estricta entre los comportamientos permitidos de aquellos reprimidos en el complejo mundo de las drogas, conlleva la caracterización exclusiva y excluyente de dos clases de sujetos: de 
una parte, el consumidor de estupefacientes que respetaba los límites de la dosis legal admisible y, de la otra, el traficante de dicha sustancia.

En ese contexto, una persona que llevara consigo o conservara alucinógenos en cantidad superior al monto permitido para su consumo, sin ser distribuidor o expendedor, carecía de una ubicación categorial explícita tanto en la Constitución como en la jurisprudencia que la desarrollaba. Tal vacío se cubrió, entonces, a partir de la naturaleza que para ese momento se adscribía a la antijuridicidad del delito, por lo que se presumía iuris et de iure que ese consumidor era narcotraficante, aun cuando ello no fuese cierto y, peor, aun cuando existiera prueba en el proceso que acreditara la realidad contraria.

\subsection{A partir del Acto legislativo No 02 de 2009.}

El Acto Legislativo No 02 de 2009 modificó el contenido del artículo 49 de la Constitución Política que, en adelante, quedaría así:

La atención de la salud y el saneamiento ambiental son servicios públicos a cargo del Estado. Se garantiza a todas las personas el acceso a los servicios de promoción, protección y recuperación de la salud.

Corresponde al Estado organizar, dirigir y reglamentar la prestación de servicios de salud a los habitantes y de saneamiento ambiental conforme a los principios de eficiencia, universalidad y solidaridad. También, establecer las políticas para la prestación de servicios de salud por entidades privadas, y ejercer su vigilancia y control. Así mismo, establecer las competencias de la Nación, las entidades territoriales y los particulares y determinar los aportes a su cargo en los términos y condiciones señalados en la ley.

Los servicios de salud se organizarán en forma descentralizada, por niveles de atención y con participación de la comunidad.

La ley señalará los términos en los cuales la atención básica para todos los habitantes será gratuita y obligatoria.

Toda persona tiene el deber de procurar el cuidado integral de su salud y de su comunidad.

El porte y el consumo de sustancias estupefacientes o sicotrópicas está prohibido, salvo prescripción médica. Con fines preventivos y rehabilitadores la ley establecerá medidas y tratamientos administrativos de orden pedagógico, profiláctico o terapéutico para las personas que consuman dichas sustancias. El sometimiento a esas medidas y tratamientos requiere el consentimiento informado del adicto.

Así mismo el Estado dedicará especial atención al enfermo dependiente o adicto y a su familia para fortalecerla en valores y principios que contribuyan a prevenir comportamientos que afecten el cuidado integral de la salud de las personas y, por consiguiente, de la comunidad, y desarrollará en forma permanente campañas de prevención contra el consumo de drogas o sustancias estupefacientes y en favor de la recuperación de los adictos (Subrayas fuera del texto original). 
Obsérvese que los dos últimos párrafos contemplan el consumo de sustancias estupefacientes o psicotrópicas como un problema de salud pública, siendo esta una novedad constitucional. En ese orden, el análisis de la reforma permite atisbar unos criterios rectores en relación a la situación problemática que por vez primera se regula expresamente en el texto superior, los cuales, entre otras cosas, encuentran pleno respaldo en los parámetros interpretativos expuestos en la sentencia C-574 de 2011, los cuales fueron reiterados en la C-882 del mismo año y en la C-491 de 2012. Tales criterios son:

1. El porte y el consumo de drogas continúan siendo conductas desvaloradas por el ordenamiento jurídico, por lo que se restringen en el grado de prohibición. Ante tal medida, la Corte Constitucional advirtió que prohibir no implicaba penalizar y que la enmienda sólo persiguió lo primero ${ }^{12}$. En relación a la teleología final de la norma en la sentencia precitada se manifestó que:

5.3.6. La finalidad del precepto, como quedó expuesto en un primer momento, buscaba acompañar a la prohibición con medidas temporales restrictivas de la libertad, que no fueran de carácter penal y que dichas medidas fueran dadas por un Tribunal mixto o de tratamiento conformado por entes judiciales y de salud. En las discusiones de la reforma este tipo de medidas fueron suprimidas dando lugar a que solo se pudieran establecer medidas preventivas y rehabilitadoras de carácter pedagógico, profiláctico y terapéutico, y siempre y cuando se haya dado el consentimiento informado del adicto.

2. El ámbito de la prohibición constitucional no cobija el porte y el consumo de drogas cuando el mismo obedece a una prescripción médica. Ello implica que ningún efecto jurídico adverso puede producir la conducta exceptuada.

3. Se determinó que la consecuencia jurídica de incurrir en el comportamiento restringido son medidas y tratamientos administrativos de orden pedagógico, terapéutico y profiláctico que, en todo caso, deben ser consentidas por el consumidor. Al respecto concluyó el Tribunal Constitucional:

5.5.1. Una vez analizado el apartado demandado desde el punto de vista sistemático, teleológico y literal, se puede concluir que la prohibición que se establece, que en un primer momento parece de carácter absoluto, se limitaría o restringiría, ya que las medidas administrativas de carácter pedagógico, terapéutico y profiláctico solo se podrían dar con el consentimiento informado del adicto.

4. Se declara al consumidor y en grado sumo al adicto como sujeto de especial atención y protección estatal, lo cual crea en su favor una discriminación positiva orientada a la prevención de comportamientos dañinos para su salud y para la de la comunidad. Esa protección reforzada se funda en que "la drogadicción crónica es una enfermedad psiquiátrica que requiere tratamiento médico en tanto afecta la autodeterminación y autonomía de quien la padece, dejándola en un estado de debilidad e indefensión que hace necesaria la 
intervención del Estado en aras de mantener incólumes los derechos fundamentales del afectado...", tal y como lo había dicho la Corte Constitucional en las sentencias T-1116 y T-814 de 2008. En esta última, inclusive, ya se había anticipado la idea según la cual:

(...) es dable afirmar que quien sufre de fármacodependencia es un sujeto de especial protección estatal, pues a la luz de la Carta Política y de la jurisprudencia constitucional, se trata de una persona que padece una enfermedad que afecta su autonomía y autodeterminación, pone en riesgo su integridad personal y perturba su convivencia familiar, laboral y social. Así las cosas la atención en salud que se requiera para tratar efectivamente un problema de drogadicción crónica, debe ser atendida por el Sistema integral de seguridad social en salud, bien a través de las empresas promotoras de salud de los regímenes contributivo y subsidiado o mediante instituciones públicas o privadas que tengan convenio con el Estado. (Negritas por fuera del texto original).

5. Se obliga al Estado a adelantar campañas de prevención contra el consumo de drogas y en favor de la recuperación de los adictos.

\section{Conclusión provisional.}

En síntesis, a partir del Acto Legislativo No 02 de 2009 puede concluirse: 1) Que si bien se prohibió a nivel constitucional el porte y el consumo de sustancias estupefacientes y sicotrópicas, también lo es que se limitó la respuesta estatal ante las conductas que violen la prohibición, a medidas de carácter administrativo; 2) Que la finalidad de la respuesta estatal será siempre pedagógica, profiláctica y terapéutica, nunca la represiva; y, 3) Que el consumidor de drogas y especialmente el adicto o farmacodependiente, fue erigido como sujeto de una protección estatal reforzada.

\section{Tendencia internacional: despenalización del consumo de estupefacien- tes y de las conductas previas}

En relación a la existencia de una tendencia contemporánea que se impone a nivel internacional y que propugna por la despenalización del porte o la tenencia para el consumo, no por mero capricho o por moda sino por los comprobados beneficios de una medida de tal naturaleza; se cita a continuación la completa y actual referencia que al respecto incluyó la Sala en la reciente sentencia de casación del 3 de septiembre de 2014, Rad. 33409:

No escapa a la Corte que en la actualidad existe una tendencia mundial hacia la despenalización del porte y consumo de dosis personal de sustancias estupefacientes, a tal punto que el pasado 13 de marzo de 2014, un Grupo de Trabajo de la Oficina de las Naciones Unidas contra la Droga y el Delito $(\mathrm{UNODC})^{13}$, presentó en Viena un informe contentivo de un conjunto de recomendaciones encaminadas a desincentivar el empleo de medidas penales para los consumidores de drogas.

Las recomendaciones de la ONU concuerdan con los informes elaborados por la "American Public Health Association", la Federación Internacional de 
la Cruz Roja, la Organización Mundial de la Salud, al igual que un grupo importante de Organizaciones no Gubernamentales.

En palabras del mencionado Informe, la despenalización de la posesión de la dosis personal, comporta mayores beneficios en términos de seguridad ciudadana y de salud pública, tales como:

- Reducción significativa del número de personas arrestadas y encarceladas.

- Aumento de la eficacia de los tratamientos contra las drogas.

- Reducción de los gastos en justicia y redireccionamiento de los recursos públicos hacia programas de salud para los drogadictos.

- Reducción de los recursos destinados a la policía y prevención de la comisión de delitos relacionados con el consumo de drogas.

- Minimización de los estigmas creados contra las personas que usan drogas.

- Mejoramiento de los programas dirigidos contra la prevención del VIHSIDA.

- Evitarle a los consumidores los traumas que implican la privación de la libertad.

Más recientemente, en el mes de julio del presente año, en un informe publicado por la Organización Mundial de la Salud (OMS) ${ }^{14}$, la Entidad manifestó su apoyo a la despenalización del consumo personal de psicoactivos. El reporte de 159 páginas se centró principalmente en la prevención y atención del VIH en el mundo e incluyó una breve sección sobre "recomendaciones de buenas prácticas relativas a la despenalización". La OMS ofreció las siguientes sugerencias:

- Los países deben trabajar hacia el desarrollo de políticas y leyes que despenalicen la inyección de drogas y otros usos y, por lo tanto, reducir el encarcelamiento.

- Los países deben trabajar hacia las políticas y leyes de desarrollo que despenalicen el uso de agujas y jeringas estériles, y la legalización de la terapia de sustitución de opiáceos (analgésicos potentes como la morfina) para las personas que son dependientes.

- Los países deberían prohibir el tratamiento obligatorio para las personas que utilizan y/o se inyectan drogas.

El pasado 13 de julio del año que transcurre, se conocieron los resultados del Estudio Nacional de Consumo de Sustancias Psicoactivas en Colombia para el año $2013^{15}$, realizado por el gobierno nacional a través del Ministerio de Justicia y del Derecho -Observatorio de Drogas en Colombia-, y el Ministerio de Salud y Protección Social, con el apoyo de la Oficina de Naciones Unidas contra la Droga y el Delito -UNODC-, la Comisión Interamericana para el Control del Abuso de Drogas -CICAD- de la Organización de Estados Americanos -OEA- y la Embajada de los Estados Unidos, en el que se determinó que el 3.3\% de los colombianos consume marihuana con 
cierta frecuencia, el $11.5 \%$ la ha probado alguna vez en su vida y 439.630 compatriotas son dependientes de esta sustancia.

Ante estas reveladoras cifras, el Ministro de Salud señaló que el aumento en el consumo de cocaína, heroína y marihuana constituye un problema de salud pública que debe ser atendido por el gobierno.

Estas declaraciones resultan concordantes con las expresadas por el Secretario Ejecutivo de la Comisión Interamericana para el Control del Abuso de Drogas -CICAD-, para la Organización de Estados Americanos -OEA ${ }^{16}$, quien el pasado 4 de noviembre destacó que el problema de la droga «debía ser tratado desde el punto de vista de la salud pública» porque "la drogodependencia es realmente una enfermedad", razón por la cual "doce países americanos han optado por despenalizar el consumo personal de drogas y pese a eso no ha aumentado su consumo», y que «esta forma de abordar el problema contribuye a evitar la sobrepoblación de las cárceles con personas que consumen pequeñas cantidades».

\section{Conclusiones generales}

Con base en el anterior análisis se puede concluir:

1. Que el consumo de estupefacientes es una conducta que no tiene la potencialidad de afectar bienes jurídicos ajenos (la salud o la seguridad pública, o el orden económico y social).

2. Que la presunción de antijuridicidad para los delitos de peligro abstracto como es el de Fabricación, tráfico y porte de estupefacientes, es iuris tantum siempre, y no sólo cuando se trate de excesos ligeros a la dosis de uso personal.

3. Que el drogadicto, incluido su entorno familiar, es sujeto de una especial protección constitucional porque es concebido como una persona enferma. Además, el consumidor en general es también sujeto de una discriminación positiva porque se establecen en su favor medidas curativas y rehabilitadoras en el nivel normativo superior.

4. Que el consumo de drogas no podría ser factor constitucional de discriminación positiva y, al tiempo, una circunstancia antijurídica, mucho menos desde el punto de vista punitivo.

Así las cosas, el porte de estupefacientes en una cantidad superior a la establecida legalmente como dosis de uso personal, es una conducta típica que se presume antijurídica. Sin embargo, como quiera que tal presunción ostenta carácter iuris tantum, la prueba de que su destino es el consumo estrictamente personal sin que apareje interferencia en derechos ajenos (orden socio-económico o la seguridad pública), desvirtúa tal suposición legal y, por ende, excluye la responsabilidad penal. En consecuencia, la cantidad de estupefaciente que se lleve consigo no es el único elemento 
definitorio de la antijuridicidad, sino sólo uno más de los que habrán de valorar los juzgadores a fin de determinar la licitud de la finalidad del porte.

Esta tesis no implica un cambio rotundo en la línea jurisprudencial que se traía, por cuanto, como se vio al principio, esta ya había despejado el camino para admitir que el porte para el consumo no vulnera los bienes jurídicos protegidos y que (en algunas ocasiones) la prueba de tal circunstancia excluía la antijuridicidad de la conducta. Por el contrario, al argumento medular que se venía sosteniendo hace casi 10 años (falta de antijuridicidad del porte de estupefacientes en algunos eventos), se le hacen producir todos los efectos que conlleva de manera plena y no parcial, como antes. Además, la tesis se ajusta de mejor manera al espíritu y al tenor del panorama constitucional que en relación al consumidor de drogas rige a partir del año 2009.

\section{Caso bajo examen}

Recuérdese que en el asunto que se analiza, la demanda de casación fue interpuesta por un delegado de la Fiscalía General de la Nación que impugnó la sentencia absolutoria proferida a favor de JOHN HENRY MONTOYA BUSTAMANTE por el delito de Tráfico, fabricación y porte de estupefaciente en la modalidad de "portar o llevar consigo". La razón fundamental del recurso extraordinario es la violación directa de la ley sustancial por interpretación errónea del artículo 4 de la Ley 599 de 2000 (Antijuridicidad), la cual habría tenido lugar cuando los falladores estimaron que el porte de 52 gramos de marihuana destinados al consumo, si bien era una conducta típica no ponía en peligro concreto los bienes jurídicos tutelados (salud pública, seguridad pública y orden económico).

Pues bien, la sola naturaleza de la única censura que formula el demandante (infracción directa) permite suponer que admite las conclusiones probatorias que en relación a los hechos investigados expuso la sentencia. Ello no admite duda alguna porque la sustentación del recurso se limitó a desarrollar una cuestión de puro derecho según la cual el fallador habría desconocido línea jurisprudencial de esta Corporación en cuanto a que sólo los excesos insignificantes podían desvirtuar la antijuridicidad del delito de porte de estupefacientes. A más de eso, de manera expresa en el libelo se reconoció uno de los fundamentos probatorios más esenciales de la decisión impugnada:

(...), para el caso de JOHN HENRY MONTOYA BUSTAMANTE, la defensa cumplió con la carga de demostrar su condición de adicto a la marihuana que fue una de las sustancias con la que fue sorprendido (también se le incautó 0.8 gramos de cocaína y sus derivados), a través de su propia manifestación $\mathrm{y}$ de testimonios rendidos por algunos familiares.

Así las cosas, a continuación se exponen esos mínimos fácticos fundamentales para la resolución del caso y sobre los cuales no existe discusión alguna. 


\section{Sentencia de primera instancia:}

De todo lo cual se debe concluir que las citadas pruebas, analizadas individual y en conjunto permiten demostrar fehacientemente la adicción del procesado. (...). Restan por verificar lo atinente a la finalidad de consumo de la droga incautada (...). Y al efecto, encontramos que los policías, testigos presenciales de los hechos, manifestaron que el lugar donde fue capturado John Henry es reconocido por ser utilizado por fumadores de marihuana, y que al capturado no lo vieron vendiendo o distribuyendo esa droga a título alguno y sí fumándola. Y adicionado a ello, se tiene que la droga incautada estaba en su estado original, es decir, no había sido dosificada en cigarrillos o porcionada en forma alguna; el procesado es una persona con arraigo familiar, social y laboral, no tiene antecedentes judiciales (...).

\section{Luego, en segunda instancia:}

(...), debe advertirse que no puede considerarse que obre ningún elemento de juicio que ubique al procesado en un contexto de tráfico, comercialización o suministro de los estupefacientes; que la situación establecida es compatible con que sea un consumidor, como quiera que en los testimonios de los agentes de la Policía Nacional que realizaron la captura, Lisandro Ibáñez Hernández y Víctor Alfonso Cadavid Sierra, fueron contestes en indicar que observaron al procesado consumiendo marihuana en un lugar boscoso donde habitualmente se consume este tipo de sustancias y que lo vieron cuando arrojó una bolsa plástica donde se encontraba el estupefaciente; además, el ex agente Ibáñez Hernández advirtió que en el lugar donde fue capturado el acusado se consume marihuana pero no se expende. Adicionalmente, de modo objetivo se encuentra que la sustancia estaba en un solo volumen de modo que sería dispendioso dedicarla a la microventa pues las dosis no estarían debidamente separadas. Estas circunstancias son indicativas de que la cantidad de alucinógeno se tenía como dosis de aprovisionamiento para el consumo del acusado, quien en su testimonio manifestó que trabaja como maestro de construcción, vive con su madre, dos hermanos y dos sobrinas, es adicto a la marihuana desde que era niño y su adicción es constante por lo que ha ido a varias instituciones buscando ayuda; pero no ha sido posible superar su padecimiento. Esta situación fue ratificada por sus hermanas Luz Ángela y Luz Mery Montoya Bustamante, y su señora madre Teresa de Jesús Bustamante de Montoya.

A partir de los pasajes transcritos se pueden relievar como supuestos fácticos probados los siguientes:

1. Que JOHN HENRY MONTOYA BUSTAMANTE realizó la conducta típica de portar o llevar consigo estupefacientes (marihuana) en cantidad de 52 gramos, la cual es superior al tope establecido en la Ley 30 de 1986 como dosis personal que es de 20 gramos.

2. Que la droga que llevaba consigo el procesado era para su propio consumo, lo cual se infirió a partir de otros hechos probados como fueron: la condición personal de consumidor habitual (adicto), el lugar en donde fue capturado es reconocido por esa actividad (no como punto de expendio 
o venta), la práctica efectiva de consumo en la que fue sorprendido por la autoridad policiva, la cantidad de droga no fue significativa atendiendo su condición de farmacodependiente (no superó en 2 veces la dosis permitida) y la presentación de la droga en una porción individualizada (no fraccionada o dividida).

Así las cosas, la conducta típica realizada por JOHN JAIRO MONTOYA BUSTAMANTE al portar marihuana en cantidad superior a la prefijada por el legislador como dosis personal, no tuvo la potencialidad de generar riesgo de lesión ni a la salud ni a la seguridad públicas ni mucho menos al orden económico y social, por cuanto la conducta indudablemente perseguía satisfacer su propia necesidad de consumo y no finalidades de tráfico. Es más, en la sentencia y en la misma sustentación del recurso, se reconoció no solo la condición de consumidor del procesado, pues inclusive era esa la actividad que desarrollaba cuando fue capturado, sino la de adicto, la cual demanda no la respuesta punitiva del Estado sino, por el contrario, la protección especial de la que es merecedor según el artículo 49 de la Constitución Política a través de medidas administrativas de orden profiláctico, terapéuticas y pedagógicas.

En conclusión, la sentencia impugnada no incurrió en una violación directa de la ley sustancial en cuanto a la interpretación de la antijuridicidad para la conducta juzgada; por el contrario, se ajustó plenamente al entendimiento que en esa materia debe prevalecer, según lo ya expuesto. Por tal razón, la providencia impugnada no será objeto de casación.

\section{Reflexión final}

En adelante, la Fiscalía General de la Nación, la Policía Nacional y los órganos de policía judicial deberán dirigir su persecución hacia los verdaderos traficantes de narcóticos que son quienes lesionan o ponen en peligro efectivamente los bienes jurídicos tutelados. En cambio, a los consumidores habrán de brindarles la protección reforzada a que también están obligados por ser todas ellas autoridades estatales.

Ahora bien, lo anterior no implica que el consumidor que incurra en conductas de tráfico ilícito de estupefacientes, no pueda ser judicializado, porque en ese proceder sí trasciende su fuero interno afectando los bienes jurídicos de la salud pública, la seguridad pública y el orden socioeconómico.

Además, si bien la Fiscalía a la hora de demostrar, como le corresponde por ostentar la carga de la prueba en el proceso penal, cada uno de los presupuestos de la conducta punible, se beneficia de la presunción legal de antijuridicidad propia de los delitos de peligro abstracto como es el Tráfico, fabricación y porte de estupefaciente; lo cierto es que el tratamiento diferenciador impuesto a nivel constitucional, así como la racionalización del poder punitivo y de la actividad judicial, imponen un mayor rigor en el acopio de elementos de conocimiento previo a la formulación de una 
imputación, que permitan o ratificar o desvirtuar la presunción de lesividad de conductas como el porte o la tenencia, pues lo contrario implica el irrazonable y desproporcionado inicio de causas cuya prosperidad dependería casi que exclusivamente de la capacidad probatoria de la contraparte.

En todo caso, con base en la valoración razonada de las pruebas o medios de conocimiento legalmente aportados por las partes, será al juez a quien corresponderá decidir si en evento de porte de estupefaciente se acreditó, o la antijurídica finalidad de tráfico o la legítima de consumo, con el propósito de que adopte la decisión que corresponda.

\section{E C I S I Ó N}

En mérito de lo expuesto, la Corte Suprema de Justicia, Sala de Casación Penal, administrando justicia en nombre de la República y por autoridad de ley,

\section{R E S U E L V E}

NO CASAR la sentencia impugnada por el delegado de la Fiscalía General de la Nación.

Cópiese, notifíquese y cúmplase.

$(\ldots)$

\section{SALVAMENTO PARCIAL DE VOTO MAGISTRADO: EUGENIO FERNÁNDEZ CARLIER}

Con el respeto que me merece el criterio mayoritario, expreso las razones por las cuales salvo parcialmente el voto en la decisión adoptada en el proceso con radicación 42.617 .

En relación con el porte de droga o sustancias alucinógenas para el consumo, la jurisprudencia de la Sala ha venido declarando que la conducta es atípica cuando la cantidad no supera los montos señalados en el artículo 2, literal k) de la Ley 30 de 1986; es típica pero no antijurídica si hay un exceso insignificante y en los demás casos es antijurídica y procede el juicio de culpabilidad.

No comparto la solución dogmática que se ofrece en la línea jurisprudencial citada, dadas las modificaciones que introdujo al ordenamiento jurídico el Acto Legislativo 02 de 2009, que en lo pertinente dispuso:

El porte y el consumo de sustancias estupefacientes o sicotrópicas está prohibido, salvo prescripción médica. Con fines preventivos y rehabilitadores la ley establecerá medidas y tratamientos administrativos de orden pedagógico, profiláctico o terapéutico para las personas que consuman dichas sustancias. El sometimiento a esas medidas y tratamientos requiere el consentimiento informado del adicto. 
Conforme al mandato constitucional citado el porte de una cantidad de droga compatible exclusivamente con el propósito de consumo es una conducta penalmente atípica, mientras que si se desvirtúa ese ingrediente subjetivo o finalidad específica, la acción corresponde a la ilicitud descrita en el artículo 376 del C.P., modificado por el artículo 11 de la Ley 1453 de 2011, pues sin ese ánimo de ingesta tal proceder pasa a ser propio del tráfico, distribución o fabricación de la sustancia ilícita que se lleve consigo.

Los antecedentes jurídicos de orden internacional e interno referidos, el argumento histórico que sirvió para la modificación que se introdujo con el acto legislativo 2 de 2009, la interpretación gramatical, sistemática y finalísima de las normas que regulan el tráfico de drogas o sustancias que producen dependencia conllevan a la ineludible conclusión que la conducta de los consumidores o adictos que porten o lleven consigo sustancias con esa específica finalidad (ingrediente subjetivo tácito del tipo penal) no pueden ser judicializados por la justicia penal, su proceder es de competencia de las autoridades administrativas de la Salud y los Gobiernos Municipales, Departamentales y Nacional, dado que el artículo 49 de la Carta Política que modificó el acto legislativo en cita solamente autorizó para que en esos casos se obrara así.

El consumidor ocasional o permanente y el adicto a las drogas no son delincuentes, son enfermos. A partir del acto legislativo 02 de 2009, dado el ingrediente subjetivo tácito establecido en esta normatividad, la sustancia portada para el consumo personal no es delictiva, la jurisdicción y autoridad competente para adelantar el trámite administrativo en esos casos es el Ministerio de Salud y solamente podrán ser sometidos a medidas educativas, profilácticas o terapéuticas.

Cualquier cantidad de droga portada con un fin distinto al consumo corresponde a la descripción típica del delito de tráfico, fabricación o tenencia de sustancias de que trata la Ley 1453 de 2011 y por ley de los contrarios la sustancia portada con el único propósito del consumo personal es una conducta que no tiene reproche criminal, de ella se ocupan las autoridades de la salud.

La cantidad de sustancia la determina la condición de consumidor, si dadas las circunstancias del caso estos conceptos no son compatibles no se está frente a un consumidor en la forma como lo regula con carácter administrativo el Acto Legislativo 02 de 2009 para aquellos, por ello la cantidad de sustancia debe ser para la ingesta personal, pues solamente así no se afecta el derecho ajeno a la salud.

3. La dosis personal comprende la de aprovisionamiento, la prevista en Colombia en la Ley 30 de 1986 no excluye una cantidad mayor. La porción que no se opone al propósito de consumo depende de la situación personal 
y el grado de dependencia del consumidor o adicto que se logre demostrar con diferentes medios de prueba (pericial, documental, testimonial, etc.

En la anterior consideración tiene importante incidencia los criterios actualizados de la ciencia y que conforme a la experiencia posibiliten determinar que la cantidad que se lleva consigo es para el consumo y no corresponde a una finalidad distinta. Por citar un ejemplo, el Tribunal Supremo de España en la sentencia 1778 del $1^{\circ}$ y 21 de noviembre de 2003 asumió los criterios del Instituto Nacional de Toxicología, según el cual un consumidor habitual adquiere cantidades para el consumo personal para 5 días en las siguientes proporciones: Heroína 3 grs, Cocaína7.5 grs., Marihuana 100 grs., Hachís 25 grs., LSD 3 mgrs., Anfetamina 900 mgrs., MDMA 1.440 mgrs.

La política criminal que sustentó la Ley 30 de 1986 no fue prohijada integralmente por el Acto Legislativo 02 de 2009. En la primera el consumo era sancionado penalmente (artículo 51 ídem) y con el segundo se despenalizó y la prohibición pasó a ser competencia de las autoridades de Salud mediante procedimientos administrativos, en la que no se pueden imponer sanciones penales sino medias que ayuden al paciente y a su familia a superar o tratar la situación.

Para comprender el cambio anunciado baste referir el criterio histórico de interpretación de la ley penal que está contenido en las consideraciones expresadas por el legislador colombiano al aprobar el ordenamiento jurídico vigente en la materia:

En el examen de la normatividad correspondiente al Acto Legislativo 02 de 2009 y se dijo:

Como se puede apreciar, la parte que hemos subrayado pone claros límites al legislador en el sentido de que las medidas que se llegaren a imponer serán de carácter pedagógico, profiláctico y terapéutico y en ningún caso penales, es decir que sería la misma Constitución la que prohibiría imponer penas de carácter estrictamente penal o como reproche a un delito consistentes en medidas restrictivas de la libertad.

El criterio expresado está avalado en la sentencia C-574 de 2011, así como por la Ley 1453 de 2011 y la sentencia C-491 de 2012 que estudió la asequibilidad (sic) de la citada Ley, y que en lo pertinente puntualizó:

"en el entendido de que el porte de sustancia estupefaciente, psicotrópica o droga sintética en cantidad considerada como dosis para uso personal, no se encuentra comprendido dentro de la descripción del delito de "tráfico, fabricación y porte de estupefaciente" previsto en esta disposición, y por ende no se encuentra penalizada.

En el estudio de la Ley 1566 de 31 de julio de 2014 se distinguió entre el consumidor, el abusador y el adicto a estupefacientes y psicotrópicos, a quienes trata como enfermos, indicándose: 


\begin{abstract}
"En conclusión quien consume sustancias psicoactivas de forma habitual o esporádica, no puede considerarse como un delincuente o una persona que se debe aislar de la sociedad porque en realidad se trata es de un ser humano en situación de enfermedad con un tipo de sintomatología que lo hace ser dependiente a diferentes tipos de estupefacientes y que por ende merece de toda la atención en salud por parte del Estado, consideración que se sustenta en lo anteriormente expuestos que resalta la Corte Constitucional" (Informe de ponencia para el segundo debate de proyecto de ley 279 de 2011 Cámara y 111 de 2010 Senado. Gaceta 214).
\end{abstract}

La sentencia C- 491 de 2012 cita como factor cuantitativo el artículo $2^{\circ}$, literal j) de la Ley 30 de 1986, alusión que constituye un obiter dicta en dicha decisión, pues el tema de la demanda de inconstitucionalidad no se ceñía a determinar la cantidad que representaba la dosis personal, por lo que la fijación de ese criterio por la Corte Constitucional conforme a sus propias enseñanzas no es de obligado acatamiento, máxime cuando ese juicio esta (sic) sustentado en un error de política criminal al acoger el de la Ley 30 de 1986 que no es el recogido por el acto Legislativo 02 de 2009.

En las legislaciones en las que el porte para el consumo es delito, los excesos de esa dosis se pueden resolver si son mínimos en el campo de la antijuridicidad material. En Colombia esa solución resulta inaplicable a partir del Acto Legislativo 02 de 2009, que despenalizó el porte para el consumo personal, por lo que toda cantidad que no sea con ese propósito, en cualquier cantidad pasa a ser tráfico o fabricación prohibida, ésta ya no es una acción de bagatela y la negación de la antijuridicidad de este último obrar depende entonces de la comprobación de alguna de las causales de justificación.

Las categorías que estructuran la conducta punible están definidas en nuestro medio en sus elementos, conceptos, contenidos y estructura, de tal forma que el juicio de tipicidad positivo, no puede generar juicios concluyentes de antijuridicidad ni estos conllevar el establecimiento de la culpabilidad. Y, ello es así porque la autonomía que genera la diferente composición de la tipicidad, antijuridicidad y culpabilidad no desnaturaliza la función armónica que cumplen en la estructuración del delito.

De lo que viene de decirse se colige que en el proceso penal no se presume la tipicidad, ni la antijuridicidad, ni la culpabilidad, sus elementos se deben demostrar en el proceso.

No se puede presumir que la conducta reúne una cualquiera de los elementos del delito, porque nuestro ordenamiento jurídico proscribe la responsabilidad objetiva e impone la carga de la prueba a la Fiscalía. Una cosa es el régimen probatorio en el proceso penal, del que hacen parte las presunciones y otra muy diferente los contenidos dogmáticos de las categorías que componen conceptualmente la conducta pública. Por ello, se insiste, en cada caso se deben probar los elementos que integran cada categoría.

Respetuosamente, (...) Fecha ut supra 


\section{ACLARACIÓN DE VOTO \\ MAGISTRADO: JOSÉ LEONIDAS BUSTOS MARTÍNEZ}

Con mi acostumbrado respeto que el criterio de mayoría merece, procedo a consignar las razones que me llevan a aclarar el voto respecto de la decisión que no casa la sentencia absolutoria proferida a favor del procesado JHON HENRY MONTOYA BUSTAMANTE, por el delito de Tráfico, fabricación o porte de estupefacientes, de la siguiente manera:

La aludida decisión declara que si la cantidad de estupefacientes que se porta sobrepasa ligeramente la dosis legal de uso personal carecerá de lesividad por su insignificancia, mientras que un exceso superior, aun cuando sea para el propio consumo se resolverá en sede de antijuridicidad teniendo en consideración el riesgo que probadamente presente para la salud pública, el orden socioeconómico y la seguridad pública.

Aclaro mi postura frente a la decisión, por cuanto estimo que no resulta constitucionalmente tolerable considerar típica la conducta de los adictos de quienes no exista prueba de que son distribuidores o expendedores, que porten sustancias alucinógenas sobrepasando ligeramente el monto previsto para la dosis personal.

En efecto, según el principio de supremacía constitucional, las normas de naturaleza penal, mediante las cuales el legislador determina aquellos comportamientos que serán objeto de sanción (principio de legalidad), no pueden ser comprendidas por los jueces acudiendo tan sólo a los clásicos métodos de interpretación de la ley. De manera que, la determinación del sentido y el alcance de las expresiones que conforman un tipo penal específico, deben ser conformes con los principios y valores constitucionales.

En este orden de ideas, partiendo de que la tipificación de los delitos configura una medida gravosa de intervención del legislador en ciertos derechos fundamentales, en especial, la libertad personal, y que esta intervención se ampara en el cumplimiento de los deberes estatales de protección (artículo 2 Superior), la interpretación y la aplicación de las normas penales, en un caso concreto, encuentra unos claros límites constitucionales, que son, entre otros, el principio de legalidad, el principio de razonabilidad, el principio de proporcionalidad, al igual que las diversas cláusulas contentivas de los derechos fundamentales. De allí que, si bien la Constitución ampara el ejercicio del ius puniendi, al mismo tiempo, impone claras fronteras al legislador y a los jueces al momento de ejercerlo.

Por esta razón, ninguna norma constitucional, incluida aquella que consagra el principio de legalidad penal (art. 29 Superior), puede ser interpretada de forma aislada, ya que la Carta Política configura una unidad, la comprensión de esta disposición constitucional debe armonizarse con las normas sobre protección de bienes jurídicamente amparados (artículo 
2 Superior,) y sobre derechos fundamentales (vgr. derecho a la vida, a la integridad personal, al libre desarrollo de la personalidad, etc.), las cuales suelen estar a menudo formuladas de manera amplia, indeterminada e incompleta (Cfr. Stern, Klaus, Derecho del Estado de la República Federal alemana, Madrid, Centro de Estudios Constitucionales, 1987, p. 285).

Por ello, la comprensión de la tipicidad penal no se agota en el texto de la ley, es decir, en la búsqueda de los significados de cada una de las expresiones que conforman un determinado tipo penal. Lo anterior por cuanto, en un Estado social de derecho, el principio de legalidad penal, puede entrar en colisión, en un caso concreto, con otros principios de rango constitucional, cuya resolución podría llevar a considerar para casos concretos, una determinada conducta como atípica. Adicionalmente, el intérprete judicial debe tener en cuenta las tendencias existentes en el mundo en una determinada materia, como puede ser, por ejemplo para el caso concreto, los cambios en las políticas públicas referidas al consumo de sustancias sicoactivas y a percibirlo más en términos de un problema de salud pública que de represión penal, actualizando así la normatividad.

Lo anterior me lleva a tener en cuenta que el 21 de diciembre de 2009 se produjo una enmienda constitucional con la expedición del Acto Legislativo 02, mediante el cual se modificó la redacción del artículo 49 Superior, que dio el tratamiento de enfermo y no de delincuente al adicto, y sustituyó para él la finalidad represiva por la de protección, a través de medidas y tratamientos administrativos de orden pedagógico, profiláctico o terapéutico, la (sic) cuales deben contar con su consentimiento informado.

Así mismo, no puedo perder de vista que la Corte Constitucional, mediante su sentencia C-574 de 2011, haciendo uso de una interpretación teleológica, sostuvo que la reforma introducida por el Acto Legislativo 02 de 2009, no pretendió penalizar la dosis personal sino prohibirla y acompañar a quienes sufren estados de alteración derivados del consumo de estupefacientes "de medidas de protección que conserven su dignidad y su vida", y que la finalidad del precepto, buscaba acompañar a la prohibición con medidas temporales restrictivas de la libertad, que no fueran de carácter penal y que se recomendaran por un Tribunal mixto o de tratamiento conformado por entes judiciales y de salud.

Sumado a lo anterior, me resulta oportuno estimar que la Corte Constitucional profirió la sentencia C-491 de 2012, tomando en consideración diversos fallos proferidos por esta Corporación, en relación con el porte de la dosis personal de estupefaciente y declaró exequible el artículo 376 de la Ley 599 de 2000, tal como fue modificado por el artículo 11 de la Ley 1453 de 2011, «en el entendido de que no incluye la penalización del porte o conservación de dosis, exclusivamente destinada al consumo personal, de sustancia estupefaciente, sicotrópica o droga sintética, a las que se refiere el precepto acusado». 
Igualmente considero que la atipicidad se extiende a los supuestos en que quien porta la sustancia estupefaciente no tiene la condición de enfermo, pero tampoco la de comerciante o distribuidor de la misma, pues establecer un tratamiento punitivo diferencial no resistiría un test de igualdad, tal y como lo ha dado por sentado la Corte Constitucional en su sentencia C-491 de 2012.

Llegar a otro tipo de conclusión nos arrojaría al absurdo de sostener que solo habrá ausencia de responsabilidad penal por atipicidad de la conducta, cuando la persona que la porta ya ha avanzado en grado tal de consumo que adquiere la condición de enfermo, desconociendo que la adicción es un proceso que se desarrolla paso a paso, iniciado con el consumo esporádico, convirtiéndose luego en consumidor habitual, hasta llegar a la categoría de adicto.

Vale la pena recordar que con base en esta ausencia de distinciones se pronunció la Corte Constitucional en su sentencia C-491 de 2012 al sostener que:

«Es preciso aclarar que la dosis personal es un concepto objetivo que hace referencia a la cantidad de sustancia estupefaciente que, de conformidad con una presunción legal, es la que resulta compatible con el consumo personal, y por ende no está destinada a la comercialización o distribución. En consecuencia, no forma parte de este concepto la condición personal de quien la "porta o conserva" en dosis mínima; es decir que resulta irrelevante para la configuración del concepto de dosis personal, la condición de adicto, consumidor habitual, o consumidor ocasional. (Subrayas fuera de texto original)».

Sin duda, el juicio de tipicidad, en un Estado Social de Derecho, no se limita a verificar si un individuo adecuó su conducta a aquella descrita previamente en un determinado tipo penal. Será igualmente necesario verificar, en el caso concreto, si aquel principio de legalidad entra en contradicción con la Constitución y la jurisprudencia emanada de ella.

Finalmente, no se debe perder de vista que actualmente existe una fuerte tendencia global hacia la despenalización de la dosis personal de drogas (Cfr. CSJ. SP. de 3 de septiembre de 2014, Rad. 33409), razón por la cual sostener la tipificación de los portes de sustancias estupefacientes de dosis personal o de cantidades levemente superiores no destinados al comercio o distribución, incluida la dosis de aprovisionamiento, iría en contravía de la corriente mundial que gira hacia su legalización y que entrega a los jueces la labor de determinar, atendiendo las especiales circunstancias de cada caso concreto, si con la cantidad de exceso se alcanza o no a vulnerar los bienes jurídicos penalmente protegidos.

Son estos razonamientos los que me llevan a aclarar mi voto.

Con mi consideración y respeto, (...). Fecha ut supra. 


\section{Notas}

$1 \quad$ El 17 de abril de 2012.

2 (i) Que el concepto y la regulación de la dosis personal prevista en el artículo $2^{\circ}$, literal j), de la Ley 30 de 1986 continúa vigente; (ii) Que en caso de porte de sustancias prohibidas en cantidad de baja significación es preciso analizar su relevancia penal a partir de la antijuridicidad material; (iii) Que el porte, tráfico o fabricación de estupefacientes para fines de comercialización son conductas antijurídicas aún si la cantidad sea igual o inferior a la dosis personal; (iv) Que cantidades insignificantes o no desproporcionadas destinadas al consumo no afectan el bien jurídico de la salud pública; y (v) Que a pesar de la prohibición introducida por el Acto Legislativo 02 de 2009 y de la modificación dispuesta por el artículo 11 de la Ley 1453 de 2011, es posible tener por impune el consumo en la dosis personal o en cantidades ligeramente superiores.

3 Luis Fernando Rey Huidobro, El delito..., ob. cit., página 25.

4 ANDREW VON HiRsch, El concepto de bien jurídico y el principio del daño, en "La teoría del bien jurídico", Madrid, Marcial Pons, 2007, páginas 38, 39, 45 y 46.

5 En el artículo $3^{\circ}$ de la Convención, denominado Delitos y Sanciones, su artículo $2^{\circ}$ dispone: "A reserva de sus principios constitucionales y a los conceptos fundamentales de su ordenamiento jurídico, cada una de las Partes adoptará las medidas que sean necesarias para tipificar como delitos penales conforme a su derecho interno, cuando se cometan intencionalmente, la posesión, la adquisición o el cultivo de estupefacientes o sustancias sicotrópicas para el consumo personal en contra de lo dispuesto en la Convención de 1961, en la Convención de 1961 en su forma enmendada o en el Convenio de 1971".

6 "Al efecto oportuno resulta señalar que en el presente asunto no solamente no se acreditó, ni siquiera se intentó arrimar prueba alguna sobre la pregonada condición de consumidor habitual de sustancias estupefacientes, menos de adicto a las mismas por parte del señor...".

7 Sentencia C-420 de 2002: "En cuanto a ello hay que decir que hay una amplia gama de derechos interferidos por el narcotráfico. Inicialmente la tipificación del tráfico de estupefacientes se ligó a la necesidad de proteger un bien jurídico en particular, la salud pública, (...).

Pero luego ese ámbito de protección se amplió al punto que hoy ya no se trata sólo de un tipo penal orientado a proteger la salud pública sino también la seguridad pública y el orden económico y social".

8 "Para que una conducta típica sea punible se requiere que lesione o ponga en peligro, sin justa causa, el interés jurídico tutelado por la ley".

9 "Para que una conducta sea punible se requiere que lesione o ponga efectivamente en peligro, sin justa causa, el bien jurídicamente tutelado por la ley penal".

10 Así se manifestó: “6. Como se recordará, con providencia del 3 de septiembre de 2003 la Corte admitió de modo discrecional la demanda excepcional de casación porque encontró, de un lado, que en cuanto a la aplicación del principio de lesividad frente a los delitos de peligro abstracto no había suficiente doctrina jurisprudencial, pues el antecedente citado en la demanda hacía referencia a un presupuesto fáctico bien diferente al que es objeto de este proceso y, de otro, 
porque en el libelo se mencionó la necesidad de fijar el alcance de la efectiva puesta en peligro a que se refiere el nuevo código penal en su artículo 11".

11 "En los tipos de peligro debe considerarse la mayor o menor cercanía de la conducta peligrosa al bien jurídico protegido. Cuando el peligro es remoto, el bien no se halla amenazado en forma concreta, y lo que en realidad se castiga es la mera desobediencia o violación formal de la ley con la realización de una acción inocua en si (sic) misma. En estos eventos la relación de causalidad entre la conducta prohibida y la actividad delictiva es enteramente contingente, y la afirmación de la existencia de dicha relación sólo puede corresponder a la elección discrecional que realiza el legislador en forma anticipada, y el juez frente al caso concreto, entre múltiples opciones; en última instancia, la potencialidad dañina que encierra la conducta se juzga realizable a partir de consideraciones que involucran no al acto mismo sino a su autor".

“5.4.3. En lo que respecta a la definición de "prohibición", el Diccionario de la Real Academia Española lo define como "el vedar o impedir el uso o ejecución de algo". Este concepto de prohibición se diferenciaría del concepto de "penalización" que se define desde el punto de vista jurídico como "el tipificar como delito o falta una determinada conducta" y desde el uso común como "el imponer una sanción o castigo". Teniendo en cuenta lo anterior, la norma no iría en contra del precedente de la Sentencia C-221 de 1994 y las Sentencias de la Corte Suprema sobre antijuridicidad material en la llamada "dosis de aprovisionamiento", ya que no se trataría de penalizar en este caso, sino de prohibir. (...)". (Negritas por fuera del texto original).

13 Cfr. http://www.drugpolicy.org/news/2014/03/united-nations-criminal-sanctions-drug-use-are-not-beneficial.

http: / / apps.who.int/iris/bitstream/10665/128048/1/9789241507431_eng. pdf? ua=1\&ua $=1$.

http: / / www.unodc.org/documents / colombia/2014/Julio/Estudio_de_ Consumo_UNODC.pdf, búsqueda del 8 de agosto de 2014. Cfr. también resultados en Revista Semana, Edición 1683, del 3 al 10 de agosto de 2014, Bogotá, pág. 44.

16 Cfr. http://www.elespectador.com/noticias/actualidad/aumenta-americatendencia-de-despenalizar-consumo-perso-articulo-456512. Búsqueda de agosto 8 de 2014. 


\section{Comentario}

\section{Primero: a manera de prenotando}

Mediante sentencia del día doce de noviembre del año pasado, la Sala de Casación Penal de la Corte Suprema de Justicia, con ponencia del Magistrado Gustavo Enrique Malo Fernández (rad. 42.617), desató el recurso extraordinario de casación interpuesto por un Fiscal Seccional de Bello contra una sentencia del Tribunal Superior de Medellín, del doce de agosto de 2013, que confirmó la absolución, por parte del Juzgado Segundo Penal del Circuito de Bello, de un ciudadano a quien, agentes de la Policía Nacional, en un 'procedimiento' realizado en "una zona boscosa del barrio París" de esa población, le decomisaron "52 gramos de marihuana y 0,8 gramos de cocaína", los cuales mantenía para el propio consumo.

No creemos que este pronunciamiento -que, por cierto, no tuvo difusión en los medios- sea la culminación de la línea jurisprudencial de esa Corporación sobre la dosis personal de estupefacientes para el autoconsumo. Sin embargo, de entrada, necesariamente, llama la atención que la Corte haya llegado a aceptar que la tenencia de 52 gramos de marihuana para el consumo personal -cantidad que supera, en mucho, la dosis personal para esta sustancia ${ }^{1}-$ no era antijurídica y, por lo mismo, no cabía deducirle, en este caso, responsabilidad jurídico penal al acusado.

Pero, antes de detenernos en ese pronunciamiento, creemos importante recordar unos antecedentes legislativos y unos precedentes jurisprudenciales de la propia Corte. En este último sentido, consideramos que hay tres 'momentos hito' en la evolución jurisprudencial sobre la dosis personal de estupefacientes para el autoconsumo: las sentencias de seis de mayo de 1980, de 18 de noviembre de 2008 $\mathrm{y}$, precisamente, la que es materia de este comentario.

\section{Segundo: el Decreto 1188 de 1974}

\section{“... es la cantidad de fármaco o droga que ordinariamente una persona ingiere, por cualquier vía, de una sola vez".}

El día 25 de junio de 1974, bajo el gobierno de Misael Pastrana Borrero, se publicó el Decreto-Ley 1188 "por el cual se expide el Estatuto Nacional de Estupefacientes" ${ }^{\prime 2}$ El art. 38 de ese Decreto reprimía, con pena de tres a doce años de presidio ${ }^{3}$, el porte, sin 
permiso de autoridad competente, de "marihuana, cocaína, morfina, heroína o cualquier otra droga o sustancia que produzca dependencia física o psíquica". Y el inciso segundo consagraba una sanción de "arresto de un mes a dos años y multa de doscientos a mil pesos", cuando "la cantidad de drogas o sustancias que el sujeto lleva consigo corresponde a una dosis personal".

El art. $6^{\circ}$ de ese Decreto definió así la dosis personal: 'Dosis personal', es la cantidad de fármaco o droga que ordinariamente una persona ingiere, por cualquier vía, de una sola vez, y 'dosis terapéutica', la que el médico normalmente prescribe al paciente.

Y, a su vez, el art. 39 de ese Decreto reguló así la determinación de la dosis personal: [1]a determinación de la dosis personal a que hace referencia el inciso $2^{\circ}$ del artículo anterior deberá hacerse por peritación médico-legal, teniendo en cuenta la calidad y cantidad de la sustancia y la historia y situación clínica del sindicado.

Eran, pues, los médicos legistas quienes, en cada proceso judicial por porte ilegal de estupefacientes, definían la suerte del sindicado: determinaban si la cantidad que ese ciudadano llevaba consigo era la que podía 'ingerir', por 'cualquier vía', 'de una sola vez', o si, por exceder ese limitado consumo, cabía, entonces, aplicar la presunción iuris et de iure según la cual esa droga estaba destinada al tráfico -venta o suministro o distribución-. También definían si ese ciudadano quedaba en libertad o si correría con todas las contingencias propias de un proceso, en el que iba a enfrentar una pena de presidio, que, por ser la más drástica de las establecidas en el Código Penal de 1936, estaba excluida, por ejemplo, de la condena condicional (el art. 80 de ese Código solo permitía la concesión de este subrogado cuando la pena era de arresto o no excedía los dos años de prisión) y en el cual, dada la situación de flagrancia de la aprehensión, muy pocas eran las posibilidades de una absolución.

Aunque los médicos legistas por lo general eran considerados y hasta benévolos en ese peritaje -en especial, en provincia-, esa facultad se prestaba, de todos modos, para abusos e incluso casos de corrupción. Pero, además, no dejaba de ser altamente cuestionable que la suerte judicial de ciudadanos por lo general pertenecientes a los sectores más vulnerables de la población por su pobreza -como suelen aquellos sorprendidos in flagranti delito de porte ilegal de estupefacientes-, estuviera sometida a tan subjetiva apreciación, así proviniera de un profesional de la Medicina, cuyos dictámenes, por 
una parte, pocas veces contaban con el soporte de una documentada historia clínica del sindicado, y, por otra, no podían ser ajenos a los preconceptos propios de la cosmovisión, en esa época, de quien los rendía, como, por ejemplo, el rechazo a 'marihuanos' o 'marihuaneros', estimados como peligrosos 'fronterizos del delito'(!).

\section{'Marihuana hierba hasta 28 gramos... Marihuana hachís hasta 10 gramos'.}

El día 9 de Abril de 1976, bajo el gobierno de Alfonso López Michelsen, previamente 'oído el parecer del Consejo Nacional de Estupefacientes', se expidió el Decreto 701, "por el cual se reglamentan los artículos $6^{\circ}, 38$, inciso $2^{\circ}$ y 39 del Decreto-Ley 1188 de 1974". En los Considerandos de ese Decreto, se consignó el siguiente razonamiento:

Que en desarrollo de la Ley 17 de 1973, el Gobierno expidió el Decreto-Ley 1188 de 1974 en el cual se consagran varias conductas delictivas en relación con estupefacientes; Que entre tales figuras es necesario diferenciar las que tipifican la elaboración y el comercio de sustancias que producen dependencia física o psíquica y aquellas que se limitan al simple porte de pequeñas cantidades para el consumo personal.

Que este último fenómeno procesal tiene previstas consecuencias especiales y por tanto reclama un tratamiento preciso y adecuado en el campo probatorio, lo que en la práctica suscita algunas dificultades técnicas...

Y su art. $4^{\circ}$ dispuso lo siguiente:

Siempre que no se demuestre que se trata de una dosis terapéutica o que sea imposible determinar mediante los criterios científicos anotados, la dosis personal del sujeto se tendrá conforme a la siguiente tabla:

Marihuana hierba hasta 28 gramos.

Marihuana hachís hasta 10 gramos.

Como es apenas entendible, la adopción por vía legislativa de la cantidad que constituía dosis personal en materia de porte de marihuana, causó un verdadero revuelo mediático: en verdad, el gobierno de López Michelsen había encontrado una solución 
muy acorde con el pragmatismo del 'Comandante Jefe', propia de su 'flema británica', de la que hacía tanta ostentación. Pero lo más trascendente es que significó una excarcelación masiva por aplicación del principio de favorabilidad normativa, pues, como siempre, la mayoría de los detenidos en las cárceles colombianas por tráfico ilegal de estupefacientes, eran personas pertenecientes a los estratos más humildes de nuestra población, en especial joven, como obreros, campesinos, estudiantes, desempleados y toda clase de 'marginados', quienes habían tenido el infortunio de que un médico forense hubiera diagnosticado que la cantidad que les había sido incautada -casi siempre poco significativa- superaba la 'dosis personal'.

Pero, como se dice, la 'dicha duró poco': mediante sentencia del día 21 de Marzo de 1977, el Consejo de Estado declaró nulo el mencionado art. $4^{\circ}$ del Decreto 701/1976. Y volvieron los señores médicos legistas a 'reinar' en la determinación de la dosis personal de estupefacientes.

Tercero: El primer 'momento hito': la sentencia de 6 de mayo de 1980

“De ahí que se entienda por 'dosis personal' tanto el consumo del total de esa cantidad como el consumo fraccionado de la misma cuando no exceda el volumen total que es propio a esta noción". "Entonces, no yerra y sí acierta el Juez que tiene por 'dosis personal' el decomiso de marihuana hierba, hasta 28 gramos, o diez gramos si se trata de marihuana hachís, no entreviéndose en esa posesión un propósito de venta o gratuito suministro a terceros, o sea evidenciándose un consumo particular y propio".

El día seis de mayo de 1980, la Sala de Casación Penal de la Corte Suprema de Justicia se pronunció sobre un recurso de casación interpuesto contra una sentencia del Tribunal Superior de Neiva, que el día seis de septiembre del año anterior había confirmado la condena a tres años de presidio impuesta a un ciudadano por el Juzgado Segundo Penal del Circuito de Florencia (Caquetá) (Revista Nuevo Foro Penal, no. 7, pp. 130-139).

Los hechos ocurrieron el día 16 de marzo de 1976 -esto es, antes de la expedición del Decreto 701- en la localidad de Puerto Rico (Caquetá); en esa ocasión fueron capturados, por agentes de policía, un estudiante y un fotógrafo, "porque el primero de ellos llevaba en su chaqueta 36 gramos de marihuana... A su captura ambos dijeron 
que les gustaba la marihuana y dejaron entrever que la portaban para el consumo personal". Al momento de la calificación del mérito sumarial, el estudiante fue enjuiciado y el fotógrafo sobreseído definitivamente. Pero, al ser consultada esta decisión exoneratoria, el Tribunal la revocó y la "mudó por enjuiciamiento". El acusado fue juzgado como reo ausente y fue capturado luego de la sentencia de primera instancia (Nuevo Foro Penal, nº 7, pp. 130-131) ${ }^{4}$.

En su pronunciamiento, la Corporación, acogiendo los planteamientos formulados por el Procurador en su concepto, sostuvo que la definición de dosis personal del art. 6 del Decreto 1188 de 1974 no debía ser interpretada en sentido literal -“la cantidad de fármaco o droga que ordinariamente una persona ingiere, por cualquier vía, de una sola vez"-; "[e]sto no equivale a que la reducida cantidad destinada a ese uso tenga que aplicarse unilateralmente, de modo integrado o total". "De ahí que se entienda por 'dosis personal' tanto el consumo del total de esa cantidad como el consumo fraccionado de la misma cuando no exceda el volumen total que es propio a esta noción" (Nuevo Foro Penal, $n^{\circ} 7$, pp. 135). Y agregó:

Buscándose conservar este sentido y evitar restricciones inadecuadas (consumo de una vez de la máxima cantidad de droga considerada como dosis personal) se insinúa como la más apropiada la locución 'dosis de aprovisionamiento para uso personal' (Proyecto de Ley $\mathrm{N}^{\circ}$ 13 de 1978, art. $1^{\circ}$, Anales del Congreso de 9 de Agosto de 1978). Pero no se quiere con esta última expresión ni ampliar la cantidad del consumo personal ni menos dilatarlo indefinidamente en el tiempo, dando margen a la posesión de mayores cantidades de droga o sustancias, lo cual propicia su aplicación a otros fines distintos al consumo personal, actividades estas verdaderamente delictuosas y sometibles a severas penas.

Tan es esto así que el aludido proyecto precisa el concepto de 'dosis personal' como 'la cantidad de sustancia, droga o fármaco que una persona porta para su propio consumo', y señala diez gramos para marihuana, cinco gramos para marihuana hachís y un gramo para cocaína, siempre y cuando que esta última tenga una concentración que no exceda del $10 \%$ y no se trate de pasta o base de coca (Nuevo Foro Penal, $n^{\circ} 7$, p. 134).

Más adelante sostuvo que era un "común e inveterado yerro de interpretación" estimar que, sin "peritación médica", "no es posible concluir que algunas porciones puedan entenderse, por sí, como propias del concepto 'dosis personal'" y que, precisamente, el 
Decreto 701 de1976 "buscó dilucidar esta equivocada valoración" (Nuevo Foro Penal, n 7, pp. 135-136).

A continuación, recordó que el Consejo de Estado no había considerado "antitécnica" la "a priori y generalizante" fijación de las cantidades considerables como dosis personales en ese Decreto, sino que las mismas obedecían a un "criterio científico". De todo lo cual se seguía que "hay situaciones en las cuales, aun sin peritación médica, puede aparecer como indubitable que se está frente a un caso de 'dosis personal', por la mínima porción que lleva consigo el usuario de esa planta o sustancia que produce dependencia física o psíquica. Y que, en otros, principalmente por su volumen, puede surgir duda al respecto, la cual disipará el respectivo dictamen médico-legal" (Nuevo Foro Penal, n 7, p. 136).

\section{Luego señaló lo siguiente:}

Conviene reiterar que tratándose de fracciones mínimas de esta clase de sustancias, drogas o plantas, determinables por la consulta de cualquier farmacopea, manual o tratado sobre el tema, es legalmente factible, sin necesidad de pericia médica, afirmar un caso de 'dosis personal', ausente como debe estar toda insinuación de comercio de esas sustancias o productos. Los conocimientos de Medicina Legal que posee el Juez, así como la experiencia y preparación especializada del funcionario penal, le permiten en no pocos eventos llegar a una determinación de esta naturaleza, sin paralizar la Administración de Justicia, o negar un tratamiento penal o médico adecuado y oportuno al procesado, o recargar innecesaria y perjudicialmente los organismos auxiliares de la justicia en el campo de la Medicina Legal, tan escasa en nuestro medio judicial. En circunstancias dudosas, bien por las características individuales del incriminado, bien por la cantidad, calidad, etc., de la droga o sustancia decomisada, será obligación acudir a la pericia médicoforense (Nuevo Foro Penal, n 7, p. 135).

Y concluyó así:

Aquí es donde las apreciaciones del Ministerio Público juegan un papel indicador de importancia. Cuando él se remite a las regulaciones del Decreto 701 de 1976, así haya sido anulado, no se está incurriendo en un desatino, sino afirmando una realidad técnica de imperiosa acogida y observación. Si ese Decreto se expidió después de oír al Consejo Nacional de Estupefacientes, que valoró aspectos científicos y pulsó la realidad nacional, no es aventurado y sí sensato aceptar que las porciones limitativas allí señaladas pueden, doctrinariamente, tomarse como guía general. Entonces, no yerra y sí acierta el Juez que tiene por 
'dosis personal' el decomiso de marihuana hierba, hasta 28 gramos, o diez gramos si se trata de marihuana hachís, no entreviéndose en esa posesión un propósito de venta o gratuito suministro a terceros, o sea evidenciándose un consumo particular y propio. En el caso de porciones superiores a las indicadas, no puede tomarse como situación inherente a la noción de 'dosis personal', a no ser que se respalde esta distinta conclusión con dictamen médico-legal que así lo demuestre y acredite (Nuevo Foro Penal, $n^{\circ} 7$, pp. 137-138) ${ }^{5}-^{6}$.

\section{Las repercusiones.}

Este pronunciamiento, que fue ampliamente divulgado por la prensa, causó gran polémica, pues hasta se llegó a afirmar que la Corte había 'legalizado' el porte de la 'dosis personal' de estupefacientes-lo que, obviamente, era falso-e implicó dos situaciones: por una parte, y como en el año 1976, generó una nueva 'masiva excarcelación'; muchos fueron los beneficiados de este avance jurisprudencial -los mismos de siempre: obreros, campesinos, estudiantes y toda clase de 'marginados' -. Y, por otra, significó el fin del 'reinado de los médicos legistas' en la determinación de la dosis personal, por lo menos en cuanto a la marihuana.

A partir de ese momento, en la praxis judicial se aceptó que cualquier cantidad de esa sustancia que se portara para el propio consumo en cantidad que no superara los 28 gramos, constituía 'dosis personal'.

\section{Cuarto: La ley 30 de 1986}

\section{"Es la cantidad de estupefacientes que una persona porta o conserva para su propio consumo".}

El día 31 de Enero de 1986, bajo el gobierno de Belisario Betancur Cuartas, se promulgó la Ley 30 "por la cual se adopta el Estatuto Nacional de Estupefacientes". Ya estábamos en el período del 'narcoterrorismo': la ofensiva de los 'extraditables' contra el Tratado de Extradición de 1979 con los Estados Unidos de América se intensificaba.

El inciso segundo del art. 33 de esta Ley estableció una pena "de uno (1) a tres (3) años de prisión y multa de cuantía de dos (2) a cien (100) salarios mínimos mensuales", cuando "la cantidad de droga exceda la dosis para uso personal sin pasar de mil (1.000) gramos de marihuana, doscientos (200) gramos de hachís, cien (100) gramos de 
cocaína o de sustancia estupefaciente a base de cocaína, doscientos (200) gramos de metacualona". Y el art. 51 criminalizó, como contraventor, a quien "lleve consigo, conserve para su propio uso o consuma, cocaína, marihuana o cualquier otra droga que produzca dependencia, en cantidad considerada como dosis de uso personal", castigándolo con una pena de "arresto hasta por treinta (30) días", extensible hasta "un (1) año" en caso de reincidencia.

Además, el art. $2^{\circ}$, en su literal j), definió lo que, en adelante, se debía tener como 'dosis personal', algunas de las cantidades de droga que constituían tal noción y lo que no debía entenderse por 'dosis personal':

Dosis para uso personal: Es la cantidad de estupefacientes que una persona porta o conserva para su propio consumo. /Es dosis para uso personal la cantidad de marihuana que no exceda de veinte (20) gramos; la de marihuana hachís la que no exceda de cinco (5) gramos; de cocaína o cualquier sustancia a base de cocaína la que no exceda de un (1) gramo, y de metacualona la que no exceda de dos (2) gramos. / No es dosis para uso personal, el estupefaciente que la persona lleve consigo, cuando tenga como fin su distribución o venta, cualquiera que sea su cantidad.

Esta disposición conllevó el fin del 'reinado de los médicos legistas en la determinación de la dosis personal' en tratándose de cualquier clase de estupefacientes. Y significó que, por varios años, en la praxis judicial, se mantuvieran, como criterios inamovibles, las cantidades señaladas en el art. 2. j) del nuevo Estatuto Nacional de Estupefacientes como constitutivas de 'dosis personal'.

\section{El principio de insignificancia.}

Sin embargo, no faltaron en la misma judicatura voces que, preocupadas por la creciente criminalización de personas pertenecientes a los estratos más humildes, por la comisión de un 'delito sin víctima' -como es el porte ilegal de estupefacientes para el autoconsumo-, planteamos alternativas para salir de esos límites normativos en los casos en los cuales las sustancias habidas superaban ligeramente la dosis personal, acudiendo, por ejemplo, al roxiniano principio de insignificancia, aplicable a la llamada 'criminalidad de bagatela' (Roxin, 1997, pp. 296-297 y 411; Cornejo, 2006; Jescheck, 1993, pp. 139, 606-607 y 777-779; Velásquez Velásquez, 2014, pp. 380-381; Zaffaroni, 1987, pp. 553-554; y Zipf, 1979, pp. 106-110). Al fin y al cabo, esa creciente prisionalización de adictos y de simples usuarios ocasionales tenía que preocupar. Y, por tal motivo, me 
atreví a sostener lo siguiente en una providencia proferida por el Juzgado Primero Penal del Circuito de Manizales, que alcanzó alguna resonancia en esa época (Velásquez Velásquez, 1990) ${ }^{7}{ }^{8}$ :

En cambio, el principio de la insignificancia brinda esa solución (...) En efecto: Si se estudia atentamente esta construcción dogmática debe concluirse que, simple y llanamente, es aplicación del principio rector de la antijuridicidad material, producto de la concepción objetiva del delito y según el cual 'para que una conducta típica sea punible se requiere que lesione o ponga en peligro, sin justa causa, el interés jurídico tutelado por la ley' (art. $4^{\circ}$ del C. Penal). Lo que no acontece en los casos que pueden ser abarcados por el aludido principio de insignificancia. Pues, en tales situaciones, es de tan poca entidad el menoscabo o riesgo sufrido por el bien jurídico que debe descartarse, por irrelevante, la dañosidad social del obrar del autor (...) Por tal motivo, en estos eventos, en los cuales, en puridad de verdad, no se produce un 'mal socio-jurídico', la imposición de una pena, que, como lo anota Juan Fernández Carrasquilla, obedece a la 'necesidad social y esta aparece frente al perjuicio real o potencial de bienes jurídicos' (1986, pág. 27), sería 'un proceder terrorista que ni siquiera merece el calificativo de Derecho' (Roxin, , 1981, p. 33.).

Podrá pensarse que la solución dada a este caso es francamente heterodoxa, pero en realidad no. Es deber de una Judicatura democrática -y todo Juez demócrata debe ser consciente de su papel de 'repartidor' de dolor y actuar guiado por esa consciencia sobre su rol como agente de control social- buscar soluciones racionales para aquellas situaciones en las que una desacertada Política Criminal del Estado, por ejemplo, por reprimir con prisión un 'delito sin víctima', desconoce abiertamente el principio de intervención mínima -el cual debe orientar a todo Derecho Penal que se diga liberal- y, por tanto, puede conducir a la comisión de flagrantes injusticias, dar lugar a la irreparable estigmatización de individuos y, fomentando la llamada desviación secundaria, propiciar el comienzo o la consolidación de carreras criminales (Revista Nuevo Foro Penal 47, 1990, p. 146). Quinto: El segundo 'momento hito': la sentencia de 18 de
noviembre de 2008

“... se resalta la necesidad de abandonar la llamada presunción «iuris et de iure» de peligro consagrada en algunos tipos penales".

El día 24 de Julio de 2001 entró a regir la Ley 599 de 2000, contentiva del actual Código Penal. Como es bien sabido, el art. 11 de este nuevo estatuto introdujo una trascendente variación al art. $4^{\circ}$ del 
Código Penal de 1980, que consagró el principio de antijuridicidad material, cuando añadió la palabra 'efectivamente' a la puesta en peligro, sin justa causa, del bien jurídico: "Antijuridicidad: Para que una conducta típica sea punible se requiere que lesione o ponga efectivamente en peligro, sin justa causa, el bien jurídicamente tutelado por la ley penal" (Subrayas propias).

Esta reforma fue explicada así en la Exposición de motivos del Proyecto de Ley N 40 de1998, que se convertiría en el actual Código Penal:

Se mantiene la norma sobre antijuridicidad, no obstante, se resalta la necesidad de abandonar la llamada presunción «iuris et de iure» de peligro consagrada en algunos tipos penales. Se clarifica que el interés jurídico protegido, cuando toma relevancia penal, se designa como bien jurídico; con lo cual se establece que necesariamente sobre el mismo debe recaer la afectación.

Y esta innovación ha llevado a algunos a predicar que, en nuestro país, los tipos penales que describen delitos de peligro abstracto o presunto, en los que 'el peligro para el bien jurídico se presume', son, como lo postula Tamayo Medina (2008, pp. 119120), inconstitucionales, pues riñen con el principio de lesividad, el cual "goza de status constitucional" en el art. $2^{\circ}$ de nuestra Norma Normarum (2008, pp. 119-120). Es que, agrega este autor, el art. 11 del Código Penal de 2000, en cuanto establece que "para que una conducta típica sea punible se requiere que lesione o ponga efectivamente en peligro, sin justa causa, el bien jurídico tutelado por la ley...convirtió los denominados delitos de peligro abstracto o presunto, en delitos de peligro concreto, efectivo o demostrable".

\section{“Lo que sí debe valorar es, en concreto, si una específica conducta significó real y verdadera puesta en peligro del bien jurídico protegido con la norma penal".}

La mencionada modificación introducida por el legislador al art. 11 del Código Penal no podía ser ajena a la jurisprudencia de la Sala de Casación Penal de la Corte Suprema de Justicia. Y es así como, el día tres de septiembre de 2003, admitió una demanda de casación excepcional presentada en un proceso adelantado por el delito de porte ilegal de armas de fuego de defensa personal, definido en el art. 365 del ordenamiento represor, por cuanto estimó conveniente un desarrollo jurisprudencial a partir de esa variación en el texto de 
la norma contentiva del principio de antijuridicidad o lesividad $\mathrm{u}$ ofensividad.

Y, en fallo del 15 de septiembre de 2004 (Tamayo, 2008 pp. 119-120), la Corte concluyó que, en los casos de delitos de peligro abstracto o presunto, debía valorarse, "en concreto, si una específica conducta significó real y verdadera puesta en peligro del bien jurídico protegido con la norma penal":

Esa delimitación entre las visiones con las cuales los dos órganos, el legislativo y el judicial, vislumbran una misma problemática, debe ser entendida con arreglo al conjunto de valores que emanan de la Constitución, pues si bien el primero, al diseñar los tipos penales de peligro abstracto asume que ciertas conductas pueden significar riesgo para determinados bienes jurídicos, es decir, establece una presunción de peligro, al segundo, al juez, le atañe verificar si un acto específico reportó efectiva creación de peligro para ese bien, porque, en 'cualquier caso, debe tratarse de un daño o de un peligro verificable empíricamente partiendo de las características de cada concreto comportamiento prohibido, y no considerando en abstracto solo el contenido de la prohibición' (Ferrajoli, 2011). Esto significa, que si bien en el momento de creación legislativa de los delitos de peligro se deja implícita una presunción de peligro, tal presunción no puede ser de aquellas conocidas como juris et de jure, es decir, que no admiten prueba en contrario, porque el carácter democrático y social del Estado de derecho, basado, ante todo, en el respeto a la dignidad humana (artículo $1^{\circ}$ de la Constitución), así lo impone, en tanto tal especie de presunción significa desconocer la de inocencia y los derechos de defensa y contradicción.

Al contrario, al evaluarse judicialmente los contornos de la conducta es ineludible establecer qué tan efectiva fue la puesta en peligro. En otro lenguaje, frente a un delito de peligro debe partirse de la base de que la presunción contenida en la respectiva norma es iuris tantum, es decir, que se admite prueba en contrario acerca de la potencialidad de la conducta para crear un riesgo efectivo al bien jurídico objeto de tutela... (Corte Suprema de Justicia - Sala Penal, sentencia no. 21064).

Y a partir de tal 'sentencia arquimédica', la C. S. J. ha desarrollado una línea jurisprudencial que se ha profundizado en fallos de fechas trece de mayo de 2009 (sentencia no. 31362) y 25 de mayo de 2010 (sentencia no. 28773) y en otras sobre porte ilegal de estupefacientes que se citarán a continuación. 


\section{“(...) si en ejercicio de sus personales e íntimos derechos, el acusado no afectó los ajenos, entonces no alteró efectivamente ningún bien jurídico, de manera que el comportamiento que se le atribuye carece de antijuridicidad material...".}

Mediante sentencia de 18 de noviembre de 2008, la Sala de Casación Penal (Rad. no. 29.183), despachó favorablemente el recurso de casación interpuesto por la defensa contra una sentencia del Tribunal Superior de Bogotá, de 12 de octubre de 2007, que confirmó la condena, por parte del Juzgado Séptimo Penal del Circuito de la capital, de un ciudadano a quien, el día 29 de marzo de 2006, en un 'procedimiento' policivo realizado 'por el sector de la carrera 70-B frente al $\mathrm{N}^{\circ} 35-07^{\prime}$, se le incautó "una bolsa transparente contentiva de 12 bolsas pequeñas de sustancia vegetal, la cual al ser sometida a estudio arrojó positivo para la marihuana con un peso neto de veintinueve punto nueve gramos (29.9 gramos)".

En este pronunciamiento -que se inscribe dentro de la línea jurisprudencial iniciada con la sentencia de quince de septiembre de 2004-, después de considerar que "la tipicidad de la conducta (desvalor de acción), no tiene discusión en este caso", concluyó que no ocurría así con su antijuridicidad:

Pero, lo que no se demuestra en la actuación es que los bienes jurídicos tutelados con el tipo penal referido (salud pública, seguridad pública, orden económico y social), hayan sido afectados con la posesión de 9,9 gramos que por encima de la dosis personal tenía en su poder el acusado, de quien se sabe es un consumidor habitual, un adicto, que no ejecutaba actividades de distribución o venta del alucinógeno.

Se pregunta la Corte si la simple posesión de la cantidad aludida por encima de la dosis personal, puede en este caso justificar la intervención del derecho penal y legitimar la imposición de una sanción.

Desde ningún punto de vista, teniendo en cuenta que en el proceso no se demostró que la conducta del acusado trascendiera la órbita de sus propios intereses, lo cual significa que la posesión de alucinógeno que se le imputa, no tuvo incidencia sobre derechos ajenos, individuales o colectivos o, lo que es igual, carece de trascendencia penal, sin que resulte válido su ejercicio so pretexto de proteger, a través del castigo, la propia salud del procesado adicto al consumo de marihuana, pues es un tema que solo corresponde decidir a él en forma autónoma por ser el único rector de su propia vida. 
En conclusión, si en ejercicio de sus personales e íntimos derechos, el acusado no afectó los ajenos, entonces no alteró efectivamente ningún bien jurídico, de manera que el comportamiento que se le atribuye carece de antijuridicidad material y, en consecuencia, no puede ser sancionado porque no alcanza la categoría de una conducta punible. El cargo analizado, en consecuencia, está llamado a prosperar.

\section{Un apuntamiento sobre los 'delitos sin víctima'.}

Este pronunciamiento de la C. S. J. fue objeto de un extenso comentario por parte de Londoño Berrío (2009, pp. 129-224), a cuyas consideraciones jurídico penales me acojo y cuyos planteamientos sociológicos, criminológicos y políticos no puedo menos que compartir (en especial, su implacable crítica al Proyecto de Acto Legislativo de reforma del art. 49 de la Constitución Política, el cual pretendió criminalizar, de nuevo, el porte de la 'dosis personal').

No voy a predicar que, en este pronunciamiento, así se diga que "los bienes jurídicos tutelados con el tipo penal referido (salud pública, seguridad pública, orden económico y social)", no fueron "afectados con la posesión de 9,9 gramos que por encima de la dosis personal tenía en su poder el acusado", se acogió, expresamente, el principio de insignificancia. Pero lo que no puede negarse es que la Corte -sin decirlo- tuvo en consideración una situación que no puede desconocerse en estos casos: se trataba de un 'delito sin víctima'. Recuérdese: "[1]a conducta del acusado", que "es un consumidor habitual, un adicto", no "trascendió" la "órbita de sus propios intereses"; "[n]o tuvo incidencia sobre derechos ajenos, individuales o colectivos".

Según Adam Bedau, citado por la criminóloga venezolana Gicovate Postaloff (1982, pp. 50-51), los delitos sin víctima presentan 'cuatro caracteres':

1) La participación consensual en los crímenes sin víctima: La homosexualidad, el aborto y la adicción a las drogas implican el consentimiento de las partes involucradas... Usualmente una persona puede llamarse víctima cuando se le causa un perjuicio, sufrimiento, etc., pero el caso de estos delitos se refiere al hecho de que una persona consiente en comprometerse en cierta actividad bajo su propio entendimiento y conocimiento.

2) Otro criterio usualmente utilizado para caracterizar esta clase de ofensas, es la ausencia de participantes demandantes: Jerome Skolnick dice que, 
por su definición, los crímenes sin víctima no son reportados. Morris y Hawkins comentan que en muchos crímenes faltan víctimas en el sentido de que no hay demandante pidiendo protección de las leyes criminales.

3) La ausencia de sentimientos de daño por parte de la 'víctima': Esto se refiere a que los crímenes sin víctimas son aquellas ofensas que no llevan consigo un sentimiento de daño hacia la persona, hasta el punto de que no impelen a llevar dicha ofensa a la atención de las autoridades.

4) La voluntariedad en hacerse dar bienes o servicios socialmente desaprobados pero ampliamente requeridos: $\mathrm{O}$ sea su naturaleza negociable o canjeable. Es este el caso del juego, el aborto, la prostitución y la adicción a la droga, en los cuales el hecho de ser ilegales tiene muy poco efecto en la reducción de sus vastas clientelas... (Gicovate Postaloff, 1982, pp. 50-51; Garrido Genoves \& Gómez Pinana, 1998, pp. 112-113; Hassemer, 1984, pp. 77, 79 y 277).

Ramírez González (1983, pp. 23-24), en uno de los estudios pioneros de Victimología publicados en el país, sostiene que, en estos casos, puede hablarse, incluso, de "víctimas auto-víctimas": "[e]s decir, que se victimizan a sí mismas". Y, para aclarar tal concepto, agrega:

Si bien la mayoría de los delitos envuelven dos participantes, el criminal y su víctima, existen casos en los cuales el criminal y la víctima se confunden en uno, no dejando de existir una víctima. Dentro de esta modalidad están, a título de ejemplo: el drogadicto, el alcohólico, el jugador. En este caso la responsabilidad no es compartida sino soportada por el mismo infractor-víctima (Ramírez, 1983, pp. 23-24).

Y en los casos de porte o conservación de estupefacientes para el propio consumo, el agente, con el empleo de la droga controlada, únicamente causase daño a sí mismo, solamente expone su salud individual, casi siempre con absoluta "ausencia de sentimientos de (ese) daño". Y si, por esa especial circunstancia de que "el criminal y la víctima se confunden en uno", ningún tercero sale perjudicado, difícilmente puede pregonarse la lesión o siquiera la puesta en peligro de un bien jurídico colectivo, como lo es, precisamente, la salud pública: la salud de los otros, de los demás, del conglomerado.

De ahí que realmente sea una barbaridad político criminal la criminalización de 'un delito sin víctima', como el porte o 
conservación de fármacos prohibidos para el consumo personal del actor: no hay una lesión o siquiera una puesta en peligro de bienes jurídicos ajenos. Y el Estado, por razón del principio de intervención mínima (Muñoz Conde, 2001, pp. 107-135; Silva Sánchez, 2010, pp. 393-397), "el cual pregona que el Derecho Penal, como última ratio del control social, solamente debe entrar a actuar cuando se registran ataques muy graves a bienes jurídicos fundamentales" (Velásquez Velásquez, 1990, p. 143), no puede reprimir conductas que no representen daño o riesgo para bienes jurídicos de terceros:

Por más que se tipifique una conducta dentro de una norma penal, sino hay en ella proyección lesiva hacia un bien jurídico, no puede ella valorarse como antijurídica. Es este el centro de definición de la antijuridicidad, y a la vez una toma de posición con relación a la misión del Derecho Penal. Se trata además de incorporar en la estructura del delito un criterio de racionalidad política-criminal que evite la sanción de conductas inocuas o de simple desobediencia a la voluntad del Estado... (Tocora López, 1990, p. 68).

Pero es más: como se expresara en una cita insertada en la providencia de quince de febrero de 1989 atrás aludida, a quien porta o conserva psicotrópicos para el auto-consumo, "el Estado no le puede contravenir el libre derecho de auto-regulación, dentro del cual se encuentra la discrecionalidad para auto-intoxicarse (como tampoco reprime las autolesiones, la tentativa de suicidio)" (Ramírez Bastidas, 1985, p. 121; Velásquez Velásquez, 1990, p. 143); tal es, ni más ni menos, una necesaria consecuencia del principio de autonomía personal. Y, precisamente, por tal motivo, la Corte Constitucional, en su famosa sentencia C-221 del 5 de mayo de 1994, declaró inexequible el art. 51 de la Ley 30 de 1986, norma que, como se recordará, criminalizaba a quien "lleve consigo o conserve para su propio uso o consuma cocaína, marihuana, o cualquiera otra droga que produzca dependencia, en cantidad considerada como dosis personal":

Cuando el Estado resuelve reconocer la autonomía de la persona, lo que ha decidido, ni más ni menos, es constatar el ámbito que le corresponde como sujeto ético: dejarla que decida sobre lo más radicalmente humano, sobre lo bueno y lo malo, sobre el sentido de su existencia. Si la persona resuelve, por ejemplo, dedicar su vida a la gratificación hedonista, no injerir en esa decisión mientras esa forma de vida, en concreto, no en abstracto, no se traduzca en daño para otro. Podemos no compartir ese ideal de vida, puede no compartirlo el gobernante, pero eso no lo hace ilegítimo. Son las consecuencias 
que se siguen de asumir la libertad como principio rector dentro de una sociedad que, por ese camino, se propone alcanzar la justicia.

Reconocer y garantizar el libre desarrollo de la personalidad, pero fijándole como límites el capricho del legislador, es un truco ilusorio para negar lo que se afirma. Equivale a esto: "Usted es libre para elegir, pero solo para elegir lo bueno y qué es lo bueno, se lo dice el Estado".

Y no se diga que todo lo que el legislador hace lo hace en función del interés común, porque, al revés, el interés común resulta de observar rigurosamente las pautas básicas que se han establecido para la prosecución de una sociedad justa. En otros términos: que las personas sean libres y autónomas para elegir su forma de vida mientras esta no interfiera con la autonomía de las otras, es parte vital del interés común en una sociedad personalista, como la que ha pretendido configurar la Carta Política que hoy nos rige.

Si el derecho al libre desarrollo de la personalidad tiene algún sentido dentro de nuestro sistema, es preciso concluir que, por las razones anotadas, las normas que hacen del consumo de droga un delito, son claramente inconstitucionales (...)

Y así también lo reconoció la Corte Suprema (2009) en esa sentencia cuando afirmó que no resultaba válido el ejercicio del Derecho Penal "so pretexto de proteger, a través del castigo, la propia salud del procesado adicto al consumo de marihuana, pues es un tema que solo corresponde decidir a él en forma autónoma por ser el único rector de su propia vida" ${ }^{\prime \prime}$.

A partir de ese momento, la Corte sentó la tesis según la cual, en algunos casos de porte de estupefacientes para el propio consumo en los cuales la cantidad de droga sobrepasara mínimamente los topes fijados por el Legislador como dosis personal, podía exonerarse de responsabilidad al autor por ausencia de antijuridicidad material:

Pero no se evidencia que el bien jurídico tutelado de la salud pública de que trata el Título XIII de la Ley 599 de 2000, se hubiese afectado por el resultado objetivo de llevar consigo 1.3 gramos de cocaína, cantidad que de manera por demás escasa sobrepasó la dosis personal, y máxime tratándose de un individuo del cual es dable inferir era un consumidor habitual, como encuentra soporte material y antecedente en la condena que por idéntico comportamiento recibió hace poco tiempo del Juzgado Cuarto Penal del Circuito de Armenia.

De otra parte, no se demostró que la conducta de J. Q. tuviera la finalidad de afectar los derechos de otros considerados de manera 
individual o colectiva, ni existe prueba en contrario con la cual deducir que el aquí procesado tenía el propósito de comerciar con la sustancia que le fue hallada. En esa medida la objetividad así valorada como llevar consigo se reporta carente de antijuridicidad material, es decir, ausente de lesividad, sin que resulte válido ni legítimo la imposición de ninguna pena y menos la de sesenta y cuatro (64) meses de prisión y $\$ 1.227 .590$ de multa, que le fuera atribuida por los jueces de instancia, pues para el caso, tan solo resulta afectada la salud del aquí procesado (auto-lesión), circunstancia que no le incumbe al derecho penal pues se trata de un comportamiento que corresponde al exclusivo ámbito de su libertad, efecto con el que se hace realidad el principio de intervención mínima o de última ratio... (Corte Suprema de Justicia - Sala Penal, sentencia no. 31531, 8 de julio de 2009.

\section{Sexto: El tercer 'momento hito': la sentencia de doce de noviembre de 2014}

\section{"No escapa a la Corte que en la actualidad existe una tendencia mundial hacia la despenalización del porte y consumo de dosis personal de sustancias estupefacientes...".}

En sentencia de tres de septiembre de 2014 (no. 33.409), la Sala de Casación Penal, realizó un recuento de las "principales líneas jurisprudenciales que, a lo largo de los años, ha elaborado -esa Corporación-en materia de porte de sustancias estupefacientes en cantidades definidas como dosis para uso personal", en las cuales diferenció dos fases: "(i) interpretación de textos legales, sin tomar en consideración argumentos de carácter constitucional; y (ii) la tesis de la ausencia de antijuridicidad material de la conducta".

De acuerdo con la C. S. J., esta última línea jurisprudencial se inició con posterioridad a la sentencia C-221 de 1994 de la Corte Constitucional.

En ese pronunciamiento, la Corte reiteró ese planteamiento:

No obstante que la Corte deba declarar la improsperidad (sic) de la primera censura propuesta en este particular evento, cabe reconocer que, tal como lo menciona el recurrente, el criterio aplicado por esta Corporación a aquellos supuestos en los cuales el adicto que no tiene la condición de comerciante o expendedor, ha sido sorprendido portando sustancias estupefacientes en cantidades ligeramente superiores a aquellas legalmente permitidas por el literal j) del artículo 2 de la Ley 30 de 1986 como dosis para uso personal, ha consistido en que esas mínimas cantidades en que se excede el porte 
permitido no alcanzan a lesionar los bienes jurídicamente tutelados por el tipo penal de tráfico, fabricación o porte de estupefacientes, generando en consecuencia su exclusión de responsabilidad criminal, cuestión que obviamente, no es el caso presente.

Más adelante sostuvo lo siguiente:

En tal orden de ideas, puede llegar a sostenerse sin hesitación alguna que, pasados todos estos cambios legislativos y pronunciamientos de la Corte Constitucional, esta Sala mantiene su línea jurisprudencial en el sentido de que (i) el solo porte de dosis para fines de uso exclusivamente personal de sustancias estupefacientes, en las cantidades y variedades establecidas por el legislador, es una conducta atípica, en cuanto no afecta bienes jurídicos ajenos, distintos de la propia salud del consumidor o del adicto; (ii) el suministro, distribución o venta de droga, o la sola tenencia o porte con fines de distribución, comercialización o venta sin permiso de autoridad competente, a la luz del ordenamiento constitucional y legal vigente, constituyen conductas delictivas, por ende sancionables penalmente, así se trate de cantidades menores a aquellas identificadas en la ley como dosis para uso personal.

Y, casi al final, agregó lo siguiente:

No escapa a la Corte que en la actualidad existe una tendencia mundial hacia la despenalización del porte y consumo de dosis personal de sustancias estupefacientes, a tal punto que el pasado 13 de marzo de 2014, un Grupo de Trabajo de la Oficina de las Naciones Unidas contra la Droga y el Delito (UNODC) ${ }^{10}$, presentó en Viena un informe contentivo de un conjunto de recomendaciones encaminadas a desincentivar el empleo de medidas penales para los consumidores de drogas.

Esta consideración llevó a alguna agencia de prensa a hablar de un "espaldarazo al uso medicinal de la marihuana", por parte de la Corte Suprema de Justicia (Elpaís.com.co, 2014).

\section{La sentencia materia del comentario. Las 'conclusiones provisionales'}

\section{“... en esta ocasión se considera que la tesis principal que se ha erigido en línea jurisprudencial debe revisarse".}

En su sentencia del 12 de noviembre de 2014, la Sala de Casación Penal, volvió a hacer un recuento acerca de la "Jurisprudencia penal sobre el porte de estupefacientes para el consumo personal". 
Al terminar, en un aparte que denominó 'conclusión provisional', sostuvo, entre otras cosas, lo siguiente:

La posición uniforme de la Corte en relación al porte de estupefacientes destinado al consumo se puede sintetizar así: si la cantidad que se lleva consigo sobrepasa ligeramente la dosis legal de uso personal carecerá de lesividad por su insignificancia. Un exceso superior, aun cuando sea para el propio consumo, siempre será antijurídico porque hace presumir -de derecho- el riesgo para la salud pública, el orden socioeconómico y la seguridad pública (...) En ese orden, se tendría que cuando el exceso es mínimo la presunción de antijuridicidad es iuris tantum porque admite prueba en contrario, como la del fin de consumo, mientras que cuando el exceso es mayor la presunción es iuris et de iure porque no admite controversia probatoria alguna.

Pero, a renglón seguido, señaló que "en esta ocasión se considera que la tesis principal que se ha erigido en línea jurisprudencial debe revisarse por cuatro razones fundamentales":

1) Porque, como se vio, en muchas de las decisiones de esta Corte ya se contemplan argumentos constitucionales, doctrinales y de derecho comparado, que permiten vislumbrar la falta de lesividad del porte de estupefacientes para el consumo.

2) Porque prohíja una doble naturaleza de la presunción de antijuridicidad en que se fundan los delitos de peligro abstracto: es iuris tantum para los eventos de exceso mínimo de la dosis personal y es iuris et de iure para las demás hipótesis, sin que exista una razón válida para una tal distinción generalizada y, además, es inconsecuente con la jurisprudencia que sobre ese punto se ha sostenido.

3) Porque a partir del Acto Legislativo No 02 de 2009 se erigió al consumidor de sustancias estupefacientes y psicotrópicas, especialmente al adicto, como sujeto de protección constitucional reforzada, lo cual impide que la misma condición que le hace merecedor de una discriminación positiva, a la vez, pueda constituir el contenido de injusticia de un delito. Y,

4) Porque la tendencia contemporánea hacia la despenalización de las conductas de porte y conservación relacionadas con el consumo de drogas, la cual predomina en distintos sectores de los gobiernos locales, de los organismos internacionales, de la academia y de la sociedad en general; obliga a la judicatura a una reflexión permanente, por lo menos, en lo que hace a efectiva antijuridicidad de tales comportamientos. 
“... necesariamente el concepto actual de la antijuridicidad como efectiva lesión o puesta en peligro de bienes protegidos, implica que la presunción de estas afectaciones pueda ser revisada e inclusive desvirtuada por la judicatura en los casos que se sometan a su conocimiento (iuris tantum)": a continuación, la Corte enfrentó el tema de los “Delitos de peligro abstracto: la presunción del riesgo es iuris tantum".

En este apartado, recordó el cambio que había implicado la ya comentada variación en la redacción del ahora art. 11 del C. Penal y. al terminar, en un apartado que denominó 'conclusión provisional', sostuvo lo siguiente:

La interpretación histórica, sistemática, exegética, pero sobre todo la de carácter constitucional que realizó la Corte en las providencias que se acaban de citar, permite afirmar que la legitimidad de la facultad del legislador para configurar delitos de peligro abstracto, especialmente hoy por el nivel exagerado de riesgo en las sociedades modernas, no conlleva que la presunción de antijuridicidad en que se fundan sea iuris et de iure; por el contrario, necesariamente el concepto actual de la antijuridicidad como efectiva lesión o puesta en peligro de bienes protegidos, implica que la presunción de estas afectaciones pueda ser revisada e inclusive desvirtuada por la judicatura en los casos que se sometan a su conocimiento (iuris tantum).

“... el consumidor de drogas y especialmente el adicto o farmacodependiente, fue erigido como sujeto de una protección estatal reforzada".

Enseguida, la Corte se ocupó del "Marco constitucional del porte de estupefacientes para el consumo personal". Este estudio lo dividió en dos acápites: antes y después del Acto Legislativo No 02 de 2009; al terminar, y en otro apartado que denominó 'conclusión provisional', sostuvo lo siguiente:

En síntesis, a partir del Acto Legislativo No 02 de 2009 puede concluirse: 1) Que si bien se prohibió a nivel constitucional el porte y el consumo de sustancias estupefacientes y sicotrópicas, también lo es que se limitó la respuesta estatal ante las conductas que violen la prohibición, a medidas de carácter administrativo; 2) Que la finalidad de la respuesta estatal será siempre pedagógica, profiláctica y terapéutica, nunca la represiva; $y, 3$ ) Que el consumidor de drogas y especialmente el adicto o farmacodependiente, fue erigido como sujeto de una protección estatal reforzada. 


\section{Una reiteración.}

Y luego, la Corte, en un acápite que tituló "Tendencia internacional: despenalización del consumo de estupefacientes y de las conductas previas", reiteró lo que sobre el particular había expuesto en la sentencia de tres de septiembre anterior.

En relación a la existencia de una tendencia contemporánea que se impone a nivel internacional y que propugna por la despenalización del porte o la tenencia para el consumo, no por mero capricho o por moda sino por los comprobados beneficios de una medida de tal naturaleza; se cita a continuación la completa y actual referencia que al respecto incluyó la Sala en la reciente sentencia de casación del 3 de septiembre de 2014, Rad. 33409....

\section{Cuatro conclusiones generales.}

Al final de esos cuatro apartados, la Corte sentó las siguientes conclusiones generales:

1. Que el consumo de estupefacientes es una conducta que no tiene la potencialidad de afectar bienes jurídicos ajenos (la salud o la seguridad pública, o el orden económico y social)

2. Que la presunción de antijuridicidad para los delitos de peligro abstracto como es el de Fabricación, tráfico y porte de estupefacientes, es iuris tantum siempre, y no solo cuando se trate de excesos ligeros a la dosis de uso personal.

3. Que el drogadicto, incluido su entorno familiar, es sujeto de una especial protección constitucional porque es concebido como una persona enferma. Además, el consumidor en general es también sujeto de una discriminación positiva porque se establecen en su favor medidas curativas y rehabilitadoras en el nivel normativo superior.

4. Que el consumo de drogas no podría ser factor constitucional de discriminación positiva y, al tiempo, una circunstancia antijurídica, mucho menos desde el punto de vista punitivo.

Así las cosas, el porte de estupefacientes en una cantidad superior a la establecida legalmente como dosis de uso personal, es una conducta típica que se presume antijurídica. Sin embargo, como quiera que tal presunción ostenta carácter iuris tantum, la prueba de que su destino es el consumo estrictamente personal sin que apareje interferencia en derechos ajenos (orden socio-económico o la segu- 
ridad pública), desvirtúa tal suposición legal y, por ende, excluye la responsabilidad penal. En consecuencia, la cantidad de estupefaciente que se lleve consigo no es el único elemento definitorio de la antijuridicidad, sino solo uno más de los que habrán de valorar los juzgadores a fin de determinar la licitud de la finalidad del porte.

Esta tesis no implica un cambio rotundo en la línea jurisprudencial que se traía, por cuanto, como se vio al principio, esta ya había despejado el camino para admitir que el porte para el consumo no vulnera los bienes jurídicos protegidos y que (en algunas ocasiones) la prueba de tal circunstancia excluía la antijuridicidad de la conducta. Por el contrario, al argumento medular que se venía sosteniendo hace casi 10 años (falta de antijuridicidad del porte de estupefacientes en algunos eventos), se le hacen producir todos los efectos que conlleva de manera plena y no parcial, como antes. Además, la tesis se ajusta de mejor manera al espíritu y al tenor del panorama constitucional que en relación al consumidor de drogas rige a partir del año 2009.

\section{La solución del caso concreto.}

La Corte afirmó que debían darse por probados los siguientes supuestos fácticos: el procesado "realizó la conducta típica de portar o llevar consigo estupefacientes (marihuana) en cantidad de 52 gramos, la cual es superior al tope establecido en la Ley 30 de 1986 como dosis personal que es de 20 gramos".

[pero] "la droga que llevaba consigo el procesado era para su propio consumo, lo cual se infirió a partir de otros hechos probados como fueron: La condición personal de consumidor habitual (adicto), el lugar en donde fue capturado es reconocido por esa actividad (no como punto de expendio o venta), la práctica efectiva de consumo en la que fue sorprendido por la autoridad policiva, la cantidad de droga no fue significativa atendiendo su condición de farmacodependiente (no superó en 2 veces la dosis permitida) y la presentación de la droga en una porción individualizada (no fraccionada o dividida)".

A continuación, expuso lo siguiente:

Así las cosas, la conducta típica realizada por JOHN JAIRO MONTOYA BUSTAMANTE al portar marihuana en cantidad superior a la prefijada por el legislador como dosis personal, no tuvo la potencialidad de generar riesgo de lesión ni a la salud ni a la seguridad públicas ni mucho menos al orden económico y social, por cuanto la conducta indudablemente perseguía satisfacer su 
propia necesidad de consumo y no finalidades de tráfico. Es más, en la sentencia y en la misma sustentación del recurso, se reconoció no solo la condición de consumidor del procesado, pues inclusive era esa la actividad que desarrollaba cuando fue capturado, sino la de adicto, la cual demanda no la respuesta punitiva del Estado sino, por el contrario, la protección especial de la que es merecedor según el artículo 49 de la Constitución Política a través de medidas administrativas de orden profiláctico, terapéuticas y pedagógicas.

\section{En tales condiciones,}

...la sentencia impugnada no incurrió en una violación directa de la ley sustancial en cuanto a la interpretación de la antijuridicidad para la conducta juzgada; por el contrario, se ajustó plenamente al entendimiento que en esa materia debe prevalecer, según lo ya expuesto".

\section{La "reflexión final".}

Una vez examinado el caso en concreto, la Corte consignó la siguiente reflexión final:

En adelante, la Fiscalía General de la Nación, la Policía Nacional y los órganos de policía judicial deberán dirigir su persecución hacia los verdaderos traficantes de narcóticos que son quienes lesionan o ponen en peligro efectivamente los bienes jurídicos tutelados. En cambio, a los consumidores habrán de brindarles la protección reforzada a que también están obligados por ser todas ellas autoridades estatales.

Ahora bien, lo anterior no implica que el consumidor que incurra en conductas de tráfico ilícito de estupefacientes, no pueda ser judicializado, porque en ese proceder sí trasciende su fuero interno afectando los bienes jurídicos de la salud pública, la seguridad pública y el orden socioeconómico.

Además, si bien la Fiscalía a la hora de demostrar, como le corresponde por ostentar la carga de la prueba en el proceso penal, cada uno de los presupuestos de la conducta punible, se beneficia de la presunción legal de antijuridicidad propia de los delitos de peligro abstracto como es el Tráfico, fabricación y porte de estupefaciente; lo cierto es que el tratamiento diferenciador impuesto a nivel constitucional, así como la racionalización del poder punitivo y de la actividad judicial, imponen un mayor rigor en el acopio de elementos de conocimiento previo a la formulación de una imputación, que permitan o ratificar o desvirtuar la presunción de lesividad de conductas como el porte o la tenencia, 
pues lo contrario implica el irrazonable y desproporcionado inicio de causas cuya prosperidad dependería casi que exclusivamente de la capacidad probatoria de la contraparte.

En todo caso, con base en la valoración razonada de las pruebas o medios de conocimiento legalmente aportados por las partes, será al juez a quien corresponderá decidir si en evento de porte de estupefaciente se acreditó, o la antijurídica finalidad de tráfico o la legítima de consumo, con el propósito de que adopte la decisión que corresponda.

\section{El salvamento de voto.}

Esta sentencia tiene un salvamento parcial de voto que puede sintetizarse en estos párrafos:

Conforme al mandato constitucional citado -Acto legislativo $\mathrm{N}^{\circ}$ 002/2009- el porte de una cantidad de droga compatible exclusivamente con el propósito de consumo es una conducta penalmente atípica, mientras que si se desvirtúa ese ingrediente subjetivo o finalidad específica, la acción corresponde a la ilicitud descrita en el artículo 376 del C.P., modificado por el artículo 11 de la Ley 1453 de 2011, pues sin ese ánimo de ingesta tal proceder pasa a ser propio del tráfico, distribución o fabricación de la sustancia ilícita que se lleve consigo (...).

(...) El consumidor ocasional o permanente y el adicto a las drogas no son delincuentes, son enfermos. A partir del acto legislativo 02 de 2009, dado el ingrediente subjetivo tácito establecido en esta normatividad, la sustancia portada para el consumo personal no es delictiva. La jurisdicción y autoridad competente para adelantar el trámite administrativo en esos casos es el Ministerio de Salud y solamente podrán ser sometidos a medidas educativas, profilácticas o terapéuticas.

Cualquier cantidad de droga portada con un fin distinto al consumo corresponde a la descripción típica del delito de tráfico, fabricación o tenencia de sustancias de que trata la Ley 1453 de 2011 y por ley de los contrarios la sustancia portada con el único propósito del consumo personal es una conducta que no tiene reproche criminal, de ella se ocupan las autoridades de la salud (...).

\section{La aclaración de voto.}

Esta sentencia tiene un salvamento parcial de voto en el que se lee lo siguiente: 
La aludida decisión declara que si la cantidad de estupefacientes que se porta sobrepasa ligeramente la dosis legal de uso personal carecerá de lesividad por su insignificancia, mientras que un exceso superior, aun cuando sea para el propio consumo se resolverá en sede de antijuridicidad teniendo en consideración el riesgo que probadamente presente para la salud pública, el orden socioeconómico y la seguridad pública.

Aclaro mi postura frente a la decisión, por cuanto estimo que no resulta constitucionalmente tolerable considerar típica la conducta de los adictos de quienes no exista prueba de que son distribuidores o expendedores, que porten sustancias alucinógenas sobrepasando ligeramente el monto previsto para la dosis personal.

En efecto, según el principio de supremacía constitucional, las normas de naturaleza penal, mediante las cuales el legislador determina aquellos comportamientos que serán objeto de sanción (principio de legalidad), no pueden ser comprendidas por los jueces acudiendo tan solo a los clásicos métodos de interpretación de la ley. De manera que, la determinación del sentido y el alcance de las expresiones que conforman un tipo penal específico, deben ser conformes con los principios y valores constitucionales....

Más adelante, después de unas breves consideraciones sobre la interpretación constitucional, señaló:

(...) la comprensión de la tipicidad penal no se agota en el texto de la ley, es decir, en la búsqueda de los significados de cada una de las expresiones que conforman un determinado tipo penal. Lo anterior por cuanto, en un Estado social de derecho, el principio de legalidad penal, puede entrar en colisión, en un caso concreto, con otros principios de rango constitucional, cuya resolución podría llevar a considerar para casos concretos, una determinada conducta como atípica. Adicionalmente, el intérprete judicial debe tener en cuenta las tendencias existentes en el mundo en una determinada materia, como puede ser, por ejemplo para el caso concreto, los cambios en las políticas públicas referidas al consumo de sustancias sicoactivas y a percibirlo más en términos de un problema de salud pública que de represión penal, actualizando así la normatividad. Lo anterior me lleva a tener en cuenta que el 21 de diciembre de 2009 se produjo una enmienda constitucional con la expedición del Acto Legislativo 02, mediante el cual se modificó la redacción del artículo 49 Superior, que dio el tratamiento de enfermo y no de delincuente al adicto, y sustituyó para él la finalidad represiva por la de protección, a través de medidas y tratamientos administrativos de orden pedagógico, profiláctico o terapéutico, los cuales deben contar con su consentimiento informado. 
Así mismo, no se puede perder de vista que la Corte Constitucional, mediante su sentencia C-574 de 2011, haciendo uso de una interpretación teleológica, sostuvo que la reforma introducida por el Acto Legislativo 02 de 2009, no pretendió penalizar la dosis personal sino prohibirla y acompañar a quienes sufren estados de alteración derivados del consumo de estupefacientes "de medidas de protección que conserven su dignidad y su vida", y que la finalidad del precepto, buscaba acompañar a la prohibición con medidas temporales restrictivas de la libertad, que no fueran de carácter penal y que se recomendaran por un Tribunal mixto o de tratamiento conformado por entes judiciales y de salud.

Sumado a lo anterior, resulta oportuno estimar que la Corte Constitucional profirió la sentencia C-491 de 2012, tomando en consideración diversos fallos proferidos por esta Corporación, en relación con el porte de la dosis personal de estupefaciente y declaró exequible el artículo 376 de la Ley 599 de 2000, tal como fue modificado por el artículo 11 de la Ley 1453 de 2011, «en el entendido de que no incluye la penalización del porte o conservación de dosis, exclusivamente destinada al consumo personal, de sustancia estupefaciente, sicotrópica o droga sintética, a las que se refiere el precepto acusado»....

Tras lo cual indicó lo siguiente:

Igualmente considero que la atipicidad se extiende a los supuestos en que quien porta la sustancia estupefaciente no tiene la condición de enfermo, pero tampoco la de comerciante o distribuidor de la misma, pues establecer un tratamiento punitivo diferencial no resistiría un test de igualdad, tal y como lo ha dado por sentado la Corte Constitucional en su sentencia C-491 de 2012.

Llegar a otro tipo de conclusión nos arrojaría al absurdo de sostener que solo habrá ausencia de responsabilidad penal por atipicidad de la conducta, cuando la persona que la porta ya ha avanzado en grado tal de consumo que adquiere la condición de enfermo, desconociendo que la adicción es un proceso que se desarrolla paso a paso, iniciado con el consumo esporádico, convirtiéndose luego en consumidor habitual, hasta llegar a la categoría de adicto....

Luego de recordar que la Corte Constitucional, en su sentencia C-491 de 2012, precisó que la "dosis personal es un concepto objetivo que hace referencia a la cantidad de sustancia estupefaciente que, de conformidad con una presunción legal, es la que resulta compatible con el consumo personal", que "por ende no está destinada a la comercialización o distribución", que, "en consecuencia, no forma parte de este concepto la condición personal de quien la 'porta o 
conserva' en dosis mínima", y que, en síntesis, "resulta irrelevante para la configuración del concepto de dosis personal, la condición de adicto, consumidor habitual, o consumidor ocasional", anotó:

Sin duda, el juicio de tipicidad, en un Estado Social de Derecho, no se limita a verificar si un individuo adecuó su conducta a aquella descrita previamente en un determinado tipo penal. Será igualmente necesario verificar, en el caso concreto, si aquel principio de legalidad entra en contradicción con la Constitución y la jurisprudencia emanada de ella.

\section{Y remató así su aclaración de voto:}

Finalmente, no se debe perder de vista que actualmente existe una fuerte tendencia global hacia la despenalización de la dosis personal de drogas (sentencia 33.409, Sala de Casación Penal, Corte Suprema de Justicia), razón por la cual sostener la tipificación de los portes de sustancias estupefacientes de dosis personal o de cantidades levemente superiores no destinados al comercio o distribución, incluida la dosis de aprovisionamiento, iría en contravía de la corriente mundial que gira hacia su legalización y que entrega a los jueces la labor de determinar, atendiendo las especiales circunstancias de cada caso concreto, si con la cantidad de exceso se alcanza o no a vulnerar los bienes jurídicos penalmente protegidos.

\section{Séptimo: apuntamientos adicionales}

\section{Una ya lejana anticipación.}

En este recuento los tres 'momentos hito' en la evolución de la línea jurisprudencial de la Sala de Casación Penal de la Corte Suprema de Justicia sobre la dosis personal de estupefacientes, hay un detalle que llama la atención: ya en la sentencia de seis de mayo de 1980, la Corte aceptó la posibilidad de que, en ocasiones, cantidades superiores a las señaladas en el art. $4^{\circ}$ del Decreto 701 de 1976, pudieran ser consideradas como constitutivas de dosis personal, en casos en los cuales "así lo demuestre y acredite" el "dictamen médico-legal" previsto en el art. 39 del Decreto 1188 de 1974.

Muchos años después, en el 2008, la Corte volvió admitir esa situación, pero, como se ha visto, por otra vía: la de la ausencia de antijuridicidad material. 


\section{La plena asunción de la presunción juris tantum en la línea jurisprudencial sobre los delitos de peligro abstracto.}

Un aspecto realmente trascendente en la sentencia de casación comentada, es la radicalización de la línea jurisprudencial sobre la antijuridicidad en los delitos de peligro abstracto -por lo menos en cuanto al porte ilegal de estupefacientes-: como se recordará, a partir de la sentencia de 15 de septiembre de 2004, y, como consecuencia de la nueva redacción del art. 11 del Codigo Penal, la Corte sostuvo que, en estos casos, la "presunción de peligro" "no puede ser de aquellas conocidas como juris et de jure, es decir, que no admiten prueba en contrario", sino que

...frente a un delito de peligro debe partirse de la base de que la presunción contenida en la respectiva norma es iuris tantum, es decir, que se admite prueba en contrario acerca de la potencialidad de la conducta para crear un riesgo efectivo al bien jurídico objeto de tutela.

Sin embargo, para la propia Corte, esta posición aún estaba sujeta a la tradicional concepción de la antijuridicidad en los delitos de peligro abstracto, como el porte de estupefacientes para el consumo personal, en cuanto se venía sosteniendo que, en estos casos, "un exceso superior, aun cuando sea para el propio consumo, siempre será antijurídico porque hace presumir -de derecho- el riesgo para la salud pública, el orden socioeconómico y la seguridad pública". $\mathrm{O}$, en otras palabras:

...se tendría que cuando el exceso es mínimo la presunción de antijuridicidad es iuris tantum porque admite prueba en contrario, como la del fin de consumo, mientras que cuando el exceso es mayor la presunción es iuris et de iure porque no admite controversia probatoria alguna.

En cambio, ahora, para la Corte, "la presunción de antijuridicidad para los delitos de peligro abstracto como el de Fabricación, tráfico y porte de estupefacientes, es iuris tantum siempre, y no solo cuando se trate de excesos ligeros a la dosis de uso personal". "Tal presunción ostenta carácter iuris tantum" y "la prueba de que su destino es el consumo estrictamente personal sin que apareje interferencia en derechos ajenos (orden socio-económico o la seguridad pública), desvirtúa tal suposición legal y, por ende, excluye la responsabilidad penal".

Esta postura conlleva, entonces, una plena asunción de dicha presunción en tal clase de hechos punibles. 
O sea que tenía razón Tamayo Medina cuando señaló que el actual art. 11 del Código Penal "convirtió los denominados delitos de peligro abstracto o presunto, en delitos de peligro concreto, efectivo o demostrable" (2008, pp. 119-120).

Lo que no deja de ser un importante avance, porque, como bien lo resaltó Londoño Berrío (2009), esa tal presunción, iuris et de jure, de "riesgo para la salud pública" cuando se portan cantidades que sobrepasan la dosis personal, pues el "excedente" "corre el riesgo de terminar en el 'mercado'", "no deja de ser una conjetura" (p. 149).

\section{El soporte constitucional: el Acto Legislativo 002 de 2009.}

Lo más paradójico de este nuevo pronunciamiento de la Corte es lo siguiente: la interpretación que -siguiendo la jurisprudencia constitucional- hace del Acto Legislativo $N^{\circ} 002$ de 2009 que reformó el art. 49 de la Constitución Política, promovido por el siempre mal recordado gobierno del 'Señor de las Sombras', con el torpe propósito de criminalizar, a toda costa, el porte de la dosis personal de estupefacientes:

[d]entro de una política integral contra la droga como la que con coherencia ha venido implementado el gobierno colombiano, donde se sanciona, se extradita, se extingue el dominio, se invierten millonarios recursos en campañas de fumigación y erradicación manual de cultivos ilícitos, etc., no es coherente ni sostenible que una conducta como el consumo o porte de sustancias estupefacientes o psicotrópicas para uso personal, no sea sancionable (Fabio Valencia Cossio y Diego Palacio Betancourt, Proyecto de Acto Legislativo 'Por medio del cual se reforma el artículo 49 de la Constitución). Colombia no puede tener esa contradicción ética de ser muy severo con producción, con tráfico, con bienes ilícitos, y al mismo tiempo ser totalmente laxo, permisivo con el consumo' (Álvaro Uribe Vélez, citado porLondoño, 2009, p. 202).

De acuerdo con ese pronunciamiento, en adelante no podrá olvidarse que "el consumidor de drogas y especialmente el adicto o farmacodependiente, fue erigido como sujeto de una protección estatal reforzada". Y aunque "el porte y el consumo de sustancias estupefacientes y sicotrópicas" quedó prohibido constitucionalmente, la "respuesta estatal" "ante las conductas que violen la prohibición", pese a tal interdicción, "será siempre pedagógica, profiláctica y terapéutica": nunca las reacciones instrumentales del derecho penal. 
Y cuando se estudian las "Conclusiones generales", la solución dada al caso concreto, la "Reflexión final", el salvamento de voto y la aclaración al mismo, podrá establecerse, sin mucha dificultad, que esa concepción del simple consumidor y del "enfermo dependiente o adicto" como "sujeto de una protección estatal reforzada", constituye, en verdad, el soporte constitucional de los razonamientos de la Corte, de quien expresó el disenso parcial y de quien aclaró su voto.

\section{De la superación del principio de insignificancia.}

Como lo apunté enantes, no me atrevo a aseverar que la Corte, en la sentencia de 18 de noviembre de 2008, acogió, expresamente, el principio de la insignificancia. Pero, en el fallo comentado, sí reconoció que la solución que venía dándole a los casos en los cuales la cantidad de droga prohibida decomisada superaba, ligeramente, la dosis personal, se fundaba en tal principio: “... si la cantidad que se lleva consigo sobrepasa ligeramente la dosis legal de uso personal carecerá de lesividad por su insignificancia".

Ahora bien, en la sentencia comentada, la Corte -para decirlo de alguna manera- superó la solución propia del principio de insignificancia y fue más allá: proclamó que, en los casos de porte de estupefacientes para el propio consumo, "es una conducta que no tiene la potencialidad de afectar bienes jurídicos ajenos (la salud o la seguridad pública, o el orden económico y social)", "no solo cuando se trate de excesos ligeros a la dosis de uso personal", sino también, y es lo más relevante, cuando se trate de una "cantidad superior a la prefijada por el legislador como dosis personal", así sea en mucho, siempre y cuando se establezca que "la conducta indudablemente perseguía satisfacer su propia necesidad de consumo y no finalidades de tráfico".

La evolución de noción de 'dosis personal de estupefacientes': de la restricción y la 'peritación médico-legal' a la determinación normativa y de la cantidad 'prefijada por el Legislador' a la indeterminación.

Como se ha visto, el Decreto 1188 de 1974 restringió la 'dosis personal' a aquella "cantidad de fármaco o droga que ordinariamente una persona ingiere, por cualquier vía, de una sola vez". Y su determinación la dejó a la "peritación medio-legal, teniendo en cuenta la 
calidad y cantidad de la sustancia y la historia y la situación clínica del sindicado".

El art. $1^{\circ}$ del Proyecto de Ley $\mathrm{N}^{\circ} 13$ de 1978 planteó el cambio de esa restringida noción por la más amplia de "dosis de aprovisionamiento para uso personal", concibiéndola como la "cantidad de sustancia, droga o fármaco que una persona porta para su propio consumo". Y así la definió la Ley 30 de 1986, aún vigente, la que, además, determinó la cantidad de sustancia que, en los casos de marihuana, marihuana hachís, cocaína o cualquier sustancia a base de cocaína y metacualona.

Durante varios años, la Corte afirmó que también podían ser consideradas como dosis personal cantidades de estupefacientes que excedieran, leve o mínima o ligeramente, la cantidad establecida en la ley, en la medida en que se comprobara que el actor llevaba consigo la droga para el propio consumo.

En el fallo comentado, la Corte aceptó que una cantidad que excedía en treinta y dos (32) gramos la dosis personal para marihuana "prefijada" en el art. 2, j) del Estatuto Nacional de Estupefacientes, no "era significativa". Y que, dado que se le mantenía para el consumo personal, "no tuvo la potencialidad de generar riesgo de lesión ni a la salud ni a la seguridad públicas ni mucho menos al orden económico y social, por cuanto la conducta indudablemente perseguía satisfacer su propia necesidad de consumo y no finalidades de tráfico".

Pero aquí, a esta altura, podría pensarse que quedó un vacío: ¿cuál será la cantidad de droga que puede portar un farmacodependiente e incluso alguien que no lo sea -obvio, sin 'finalidades de tráfico'-, para que se le siga considerando como 'poco significativa'? No creo que haya ningún vacío: la Corte no podía fijar límites a las cantidades que, en los casos de adictos o de ciudadanos que solo son usuarios ocasionales de sustancias psicotrópicas, pueden estimarse como constitutivas de 'dosis personal': no estaba legislando. Pero, además, no podía alejarse del "soporte constitucional" de su pronunciamiento: "Que el consumidor de drogas y especialmente el adicto o farmacodependiente, fue erigido como sujeto de una protección estatal reforzada...".

Lo anterior significa, ni más ni menos, que, en estos momentos, estamos ante una indeterminación en cuanto a las cantidades 
que constituyen la dosis personal de drogas o sustancias -como marihuana o cocaína- en casos de 'adictos' o 'farmacodependientes' o de usuarios ocasionales de fármacos prohibidos, cuando se tienen para el auto-consumo (!).

Lo relevante es que, en estos asuntos, se acredite que "la conducta indudablemente perseguía satisfacer su propia necesidad de consumo y no finalidades de tráfico". Y, siendo así, según la Corte, no habrá más alternativa que una exención de responsabilidad jurídico-penal por ausencia de antijuridicidad material.

\section{No es la culminación de la línea jurisprudencial sobre la dosis personal de estupefacientes.}

\section{"... es una conducta penalmente atípica".}

Como se recordará, la sentencia comentada tuvo un salvamento parcial de voto, no porque quien lo suscribió estuviera en desacuerdo con algún aspecto sustancial de la posición mayoritaria, sino porque asumió un punto de vista más radical.

Es que, de acuerdo con el disidente, por razón del "mandato constitucional citado -Acto legislativo $N^{\circ} 002$ de 2009- el porte de una cantidad de droga compatible exclusivamente con el propósito de consumo es una conducta penalmente atípica": "dado el ingrediente subjetivo tácito establecido en esta normatividad, la sustancia portada para el consumo personal no es delictiva"; "la sustancia portada con el único propósito del consumo personal es una conducta que no tiene reproche criminal".

\section{"Medidas temporales restrictivas de la libertad, que no fueran de carácter penal".}

Esa radical estimación como atípica de la conducta de quien porta estupefacientes para el propio consumo, fue expuesta, con mayor contundencia -y por ello me atreví a transcribirla casi in integrum-, en la aclaración del voto, donde se recordó que el Acto Legislativo $\mathrm{N}^{\circ} 002$ de 2009

no pretendió penalizar la dosis personal sino prohibirla y acompañar a quienes sufren estados de alteración derivados del consumo de estupefacientes 'de medidas de protección que conserven su dignidad y su vida', y que la finalidad del precepto, buscaba acompañar a la 
prohibición con medidas temporales restrictivas de la libertad, que no fueran de carácter penal.

Siendo así las cosas, como lo apunta el autor de la aclaración:

(...) no resulta constitucionalmente tolerable considerar típica la conducta de los adictos de quienes no exista prueba de que son distribuidores o expendedores, que porten sustancias alucinógenas sobrepasando ligeramente el monto previsto para la dosis personal". Y, además, esa atipicidad, ineludiblemente, debe "extenderse" "a los supuestos en que quien porta la sustancia estupefaciente no tiene la condición de enfermo, pero tampoco la de comerciante o distribuidor de la misma, pues establecer un tratamiento punitivo diferencial no resistiría un test de igualdad, tal y como lo ha dado por sentado la Corte Constitucional en su sentencia C-491 de 2012.

Conclusión diversa, de conformidad con la aclaración de voto,

...arrojaría al absurdo de sostener que solo habrá ausencia de responsabilidad penal por atipicidad de la conducta, cuando la persona que la porta ya ha avanzado en grado tal de consumo que adquiere la condición de enfermo, desconociendo que la adicción es un proceso que se desarrolla paso a paso, iniciado con el consumo esporádico, convirtiéndose luego en consumidor habitual, hasta llegar a la categoría de adicto.

\section{Principio de fragmentariedad y atipicidad.}

Si bien el Acto Legislativo $N^{\circ} 002$ prohibió "el porte y el consumo de sustancias estupefacientes o sicotrópicas", su "tratamiento administrativo de orden pedagógico, profiláctico o terapéutico", situó ese comportamiento, al mismo tiempo, en predios del injusto extrapenal: téngase en cuenta que, como lo resaltó la aclaración de voto, por expresa voluntad del legislador, la respuesta frente a tal conducta se redujo a la adopción de "medidas temporales restrictivas de la libertad, que no fueran de carácter penal".

Aquí no debe olvidarse el principio de fragmentariedad del derecho penal, íntimamente vinculado al principio de intervención mínima: aunque en cada rama del ordenamiento se presentan comportamientos contra legem, no cualquier acto ilícito se sitúa dentro del campo del derecho penal, cuyas violaciones son sancionadas con penas criminales: "[1]as conminaciones penales no tienen por qué extenderse a todas las infracciones" (Cobo Del Rosal 
\& Vives Antón, 199, p. 70) ${ }^{11}$. Simplemente, el legislador selecciona, entre todos los injustos, aquellos que representan los más extremos atentados contra bienes jurídicos fundamentales para la convivencia humana y los convierte en injustos penales: protege tales bienes jurídicos mediante la conminación de penas criminales a conductas que impliquen su lesión o puesta, efectivamente, en peligro.

O sea que, en virtud del principio de fragmentariedad -algunos hablan del carácter 'fragmentario'-, el derecho penal solo sanciona los injustos más graves y que, por tal motivo, resultan intolerables para la coexistencia social. Y de ahí que se diga que el derecho penal únicamente se ocupa de un fragmento del injusto total: de "toda esa gama de conductas que el sistema jurídico manda o prohíbe", "solo eleva al rango de conductas mandadas o prohibidas una parte de las que los demás sectores del orden jurídico consideran antijurídicas" (Velásquez, 2009, p. 185; Velásquez, 2014, p. 108) ${ }^{12}$. Y las ilicitudes no seleccionadas para su sanción mediante una pena criminal, se tornan, desde la perspectiva jurídico penal, en atípicas: más aún, en absolutamente atípicas ${ }^{13}$.

Tal ha acontecido en materia del porte de la dosis de estupefacientes de uso personal: aunque el legislador declaró su prohibición, la mandó, de una, al campo del injusto extrapenal. Por fortuna, nuestro legislador aquí, al tomar esta determinación, obró, sin saberlo, como lo señalaba Welzel:

[e]l Derecho Penal se extiende más allá de sí mismo y se inserta en el marco cultural de una época. Pero este efecto lo logra solo a través de una sabia circunscripción de sus medios. Un penar a diestra y siniestra mellaría sus armas (1993, p. 6).

Por tal potísimo motivo, cuando, como lo enfatiza la propia Corte, se establece que la conducta del sujeto-agente -adicto o farmacodependiente o usuario ocasional- "indudablemente perseguía satisfacer su propia necesidad de consumo y no finalidades de tráfico", debe reputarse que tal acción es -como se planteó tanto en el salvamento parcial de voto como en la aclaración-, simple y llanamente, atípica: no incursiona -ni de lejos- dentro del campo del derecho penal. Como, por cierto, se dijo en la sentencia de 3 de septiembre de 2014:

(...) el solo porte de dosis para fines de uso exclusivamente personal de sustancias estupefacientes, en las cantidades y variedades establecidas por el legislador, es una conducta atípica, en cuanto no afecta bienes jurídicos ajenos, distintos de la propia salud del 
consumidor o del adicto (Sala de Casación Penal, Corte Suprema, sentencia 33.409).

De ahí que pensemos que si la Corte, en su evolución jurisprudencial sobre el tema, es consecuente con el soporte constitucional del comentado pronunciamiento -que "el consumidor de drogas y especialmente el adicto o farmacodependiente", lo mismo que el usuario episódico, "fue erigido como sujeto de una protección estatal reforzada" y su tratamiento es extrapenal- tendrá que concluir, a la postre, como lo admitió anteriormente y lo preconizaron el salvamento y la aclaración de voto, que "el porte de una cantidad de droga compatible exclusivamente con el propósito de consumo es una conducta penalmente atípica".

Por eso, entonces, estimamos que el fallo materia de este comentario no es la culminación de la línea jurisprudencial sobre la dosis personal de estupefacientes.

Solo cabría esperar que, en este tema, no se produzca una repentina involución, como la que se dio con las líneas jurisprudenciales relativas al principio de inmutabilidad judicial -en materia jurídicoprocesal- ${ }^{14} \mathrm{y}$ a la lex tertia -en la aplicación del principio constitucional de favorabilidad normativa- ${ }^{15}$.

\section{Séptimo: final: ¿el comienzo del adiós a una 'pena alucinante' para un 'delito sin víctima'?}

En su sentencia del día 12 de noviembre del año pasado, la Sala de Casación Penal de la Corte Suprema de Justicia recordó lo que ya había señalado en su fallo de tres de septiembre anterior: existe una

...tendencia contemporánea hacia la despenalización de las conductas de porte y conservación relacionadas con el consumo de drogas, la cual predomina en distintos sectores de los gobiernos locales, de los organismos internacionales, de la academia y de la sociedad en general.

Y esa tendencia "obliga a la judicatura a una reflexión permanente, por lo menos, en lo que hace a la efectiva antijuridicidad de tales comportamientos".

Alrededor del fallo comentado, cabrían muchas más disquisiciones jurídico penales y criminológicas. Pero he tratado de destacar los aspectos centrales de ese pronunciamiento y extraer, a partir de 
las mismos, algunas premisas que inviten a esa "reflexión permanente" a la que llama la Corte, la que no debe ser tarea solo de la judicatura, sino, principalmente, de la academia.

Hoy en día, la pena mínima para quien sea sorprendido en el porte de 'cantidad de droga' que 'exceda' la dosis personal en drogas como marihuana, hachís, cocaína o sustancia estupefaciente a base de cocaína, derivados de la amapola, droga sintética, nitrato de amilo, ketamina y GHB, es de sesenta y cuatro (64) meses de prisión. Y esa sanción -así, por ejemplo, se allane a cargos en los inicios del proceso ${ }^{16}$ no solo le hace esquiva al procesado la concesión del subrogado de la suspensión condicional de la ejecución de la pena ${ }^{17}$, sino también como lo aducen muchos ${ }^{18}$ - el otorgamiento de la prisión domiciliaria. Lo que significa que, sea como sea, habrá "reclusión intramural" para ese ciudadano. Y, como siempre, la población carcelaria que 'recluta' el sistema penal en materia de porte ilegal de estupefacientes, es la misma: en especial, jóvenes pertenecientes a los sectores más vulnerables de la población por su pobreza, obreros, campesinos, estudiantes y toda clase de 'marginados'.

Un grupo de analistas de la corporación Dejusticia publicó, no hace mucho tiempo, un estudio intitulado Penas alucinantes (La desproporción de la penalización de las drogas en Colombia) (Uprimny et al, 2013) ${ }^{19}$, en el cual, por ejemplo, demuestran que, con "relación a la conducta de tráfico, fabricación o porte de estupefacientes", "un análisis de la evolución legislativa permite identificar un aumento considerable tanto en la pena mínima como en la pena máxima determinadas por el Legislador": "la pena mínima ha aumentado en cerca de un $2.000 \%$, y la pena máxima en un 600\%" (Uprimny et al, 2013).

Es posible que para muchos la cifra de sesenta y cuatro (64) meses de prisión no les diga mayor cosa -pues ni siquiera tienen noticia de esa 'alucinante' evolución legislativa- y no se detengan a meditar en lo que ese tiempo representa en la vida de cualquier persona. Pero acudamos a un caso hipotético: si el consumo de licor estuviera criminalizado y sucediera que alguien pudiera ser encarcelado por ese tiempo -sesenta y cuatro (64) meses-, porque, por ejemplo, portaba dos (2) botellas de aguardiente o de ron o de brandy o de whisky -bebidas todas productoras de dependencia-, cuando era una (1) lo permitido por la ley, ahí sí concluirían, sin necesidad de grandes esfuerzos conceptuales, que tal castigo para un joven -que podría ser nuestro hijo o nuestro nieto o nuestro hermano menor-, 
es, en verdad, una pena alucinante. El caso hipotético también podría plantearse con el consumo de tabaco, cuyo componente nicotina es, como todo el mundo lo sabe, altamente adictivo.

Entonces, en el actual contexto, donde se abre paso la opción de la despenalización del porte y de la tenencia para el consumo, la sentencia comentada no puede ser menos que bienvenida, pues representa un paso más en un proceso histórico que puede terminar con la erradicación de otra de las tantas 'penas alucinantes' ingeniadas por los dueños del poder de definición en nuestra sociedad.

Por consiguiente, sí, ese pronunciamiento puede ser, entre nosotros, el comienzo del adiós a una "pena alucinante" para un "delito sin víctima". Y ojalá se entienda a partir de ahora que, como lo resaltó la propia Corte en su sentencia (rad. 29.183) de 18 de noviembre de 2008, jamás puede ser válido el ejercicio del derecho penal "so pretexto de proteger, a través del castigo, la propia salud del procesado adicto al consumo de marihuana, pues es un tema que solo corresponde decidir a él en forma autónoma por ser el único rector de su propia vida".

Es que tal clase de empleo del poder punitivo solo puede demostrar aquello que, en tiempos de auge de la Criminología Crítica y de las tendencias abolicionistas ${ }^{20}$, se denunciaba con tanto énfasis: ¡la irracionalidad del derecho penal -ese mecanismo transmisor de "dolor deliberado" 21 - como instrumento de control social! (Yacobucci, 2000, p. 277).

Manizales, Febrero de 2015.

\section{Notas}

1 Fijada por el literal j) del art. $2^{\circ}$ de la Ley 30 en la "cantidad que no exceda de veinte (20) gramos de marihuana".

2 Sobre los antecedentes legislativos del tratamiento del tráfico y porte de estupefacientes, Cfr. Velásquez (1989, pp. 2-18).

3 El art. 41 del C. P de 1936 (Ley 95) consagraba, originalmente, cinco penas principales: presidio, prisión, arresto, confinamiento y multa. La pena de presidio desapareció de nuestra Legislación a partir de la entrada en vigencia del C. Penal de 1980 (Decreto 100).

4 Hacían parte de la Sala de Casación Penal magistrados como Fabio Calderón Botero, Alfonso Reyes Echandía, Pedro Elías Serrano Abadía 
y Darío Velásquez Gaviria, sacrificados en los hechos del Palacio de Justicia del 5 y 6 de Noviembre de 2005; el ponente fue el Magistrado Gustavo Gómez Velásquez.

5 La sentencia de la C. S. J. no comportó la absolución del procesado, sino la nulidad del proceso.

6 Hubo un salvamento parcial de voto de los magistrados Fabio Calderón Botero y Alfonso Reyes Echandía, quienes creyeron "inconveniente e innecesario que la Corte se ocupe, como Tribunal de instancia, de casación o de revisión, de un Proyecto de Ley para acogerlo o rechazarlo total o parcialmente". Y, además, no compartieron "el acogimiento por la mayoría de la Sala al nuevo concepto de 'dosis de aprovisionamiento personal' con que el Proyecto $\left(\operatorname{art.~} 1^{\circ}\right.$ ) pretende reemplazar el de 'dosis personal'"' (Revista Nuevo Foro Penal, 7, pp. 130-139).

7 Auto del 15 de febrero de 1991 del Juzgado Primero Penal del Circuito de Manizales, publicado parcialmente en la revista Nuevo Foro Penal, N 47, Editorial Temis, Bogotá, 1990, pp. 141-147, con el título de "El porte de insignificante cantidad de droga como delito inocuo", con comentario de Fernando Velásquez Velásquez. También, Gómez Pavajeau (1991, pp. 97-98) y Pérez Pinzón (2000, p. 197).

8 La tesis expuesta en esa providencia, fue resumida así por Fernando Velásquez Velásquez: "[e]l porte de 1.1 grs. de bazuca no lesiona realmente el bien jurídico Salud Pública, caso en el cual se está en presencia de un injusto de bagatela que, por su insignificancia, no cumple con la condición de antijuridicidad material que debe cumplir todo hecho punible, según el mandato del art. $4^{\circ}$ del C. Penal" (1990, p. 141).

9 Así se reiteró en la sentencia de casación de fecha 8 de julio de 2009: "Lo que se pone de presente es un comportamiento 'auto-destructivo' o de 'auto-lesión' el cual incumbe los ámbitos exclusivos de la libertad de esa persona, es decir, a un fenómeno singular carente de antijuridicidad material (ausencia de lesividad) y que, por ende, no es punible" (Corte Suprema de Justicia, Sala Penal, sentencia no. 31.531, de ocho de julio de 2009.).

10 "Cfr. http://www.drugpolicy.org/news/2014/03/united-nationscriminal -sanctions-drug-use-are-not-beneficial".

11 Aquí debe recordarse a Hans Welzel (1993): “Cuando las disposiciones penales constriñen casi todas las actividades vitales, cuando hasta los actos de defensa de la existencia pueden ser punibles, entonces el Derecho Penal padece exceso de punición", (pp. 6-7).

12 Sobre el principio de fragmentariedad, Cfr., entre otros, Gómez de la Torre et al (2010, p. 73), Fernández Carrasquilla (2011, p. 257), Jescheck 
(1993, pp. 45-46); Muñoz Conde \& García Arán (2012, pp. 79-80); Welzel (1993, pp. 6-7) y Zugaldia et al, (2010, pp. 94-95).

13 Aunque toda atipicidad objetiva es 'absoluta', pues no existe una 'atipicidad relativa', utilizo el término 'absolutamente', para enfatizar la irrelevancia jurídico penal de una conducta atípica.

14 Sobre el desmonte de los alcances de esta línea jurisprudencial, que implicó, por ejemplo, el abandono de la concepción del Juez natural en el Sistema Penal Acusatorio como "el Juez del juicio del oral", y el no disimulado restablecimiento del 'principio de permanencia de la prueba' (Cfr. Sala de Casación Penal, Corte Suprema, sentencias (diciembre 12 de 2012), 31362; 38.512, (julio de 3 2013), 38.632).

15 Sobre el desmonte de línea jurisprudencial de la aplicación de la lex tertia -que, según la misma Corte, significaba "una especie de conjugación normativa que reivindica a plenitud el principio de favorabilidad"(Cfr. Sala de Casación Penal, Corte Suprema, sentencia (marzo 12 de 2014) $\left.\mathrm{N}^{\circ} 42.623\right)$.

16 Recuérdese que hoy en día, por razón del parágrafo del art. 301 del C. de P. Penal, la rebaja en casos de flagrancia es sólo de "un cuarto $(1 / 4)$ del beneficio de que trata el art. 351 de la Ley 906 de 2004".

17 El Art. 63 del C. Penal, modificado por el art. 29 de la Ley 1.709 de 2014, permite su otorgamiento cuando "la pena impuesta sea de prisión que no exceda de cuatro (4) años".

18 Con apoyo en el inciso segundo del art. 68-A del C. Penal, modificado por el art. 32 de la Ley 1.709 de 2014.

19 Cfr. sobre el mismo tema, pero a nivel continental, Pérez Correa (Pérez Correa et al, 2012).

20 Cuyos principales postulados se mantienen vigentes, así hoy en día estén predominando otras tendencias.

21 Según Nils Cristie (1984, p. 7), "la imposición de un castigo dentro del marco de la ley significa causar dolor, dolor deliberado...".

\section{Referencias}

Auto (1989, febrero 15). César Augusto López Londoño. Juzgado Primero Penal del Circuito de ManizalesNo hay ninguna fuente en el documento actual.

Berdugo Gómez de la Torre, I. et al. (2010). Curso de Derecho Penal (Parte General), segunda edición, Barcelona: Ediciones Experiencia, Barcelona. 
Cobo Del Rosal, M., \& Vives Antón. (1993). Derecho Penal. Parte General. Valencia: Tirant.

Cornejo, A. (2006). Teoría de la insignificancia. Buenos Aires: Rubinzal Culzoni.

Christie, N. (1984). Los límites del dolor. México: Fondo de la Cultura Económica

Elpaís.com.co. Espaldarazo al uso medicinal de la marihuana. (7 de Octubre de 2014). COLPRENSA.Recuperado de http://www.elpais. com.co/elpais/colombia/noticias/corte-da-espaldarazo-proyecto-usomedicinal-marihuana

Fernández Carrasquilla, J. (1986). Derecho Penal Fundamental. Bogotá: Temis.

Fernández Carrasquilla, J. (2011). Derecho Penal. Parte General. Bogotá: Grupo Editorial Ibáñez.

Ferrajoli, L. (2011). Derecho y Razón. Teoría del garantismo penal. Madrid: Trotta.

Garrido Genoves, V., \& Gómez Pinana, A. (1998). Diccionario de Criminología. Valencia: Tirant lo Blanch.

Gicovate Postaloff, M. (1982). Los procesos de descriminalización. Caracas: Universidad Central de Venezuela.

Gómez Pavajeau, C. A. (1991). El principio de antijuridicidad material. Bogotá: Imprenta Nacional de Colombia.

Hassemer, W. (1984). Fundamentos del Derecho Penal. Barcelona: Bosch.

Jescheck, H.-H. (1993). Tratado de Derecho Penal Parte General. Granada: Comares.

Londoño Berrío, H. L. (2009). Los avatares de la "dosis personal": de derecho constitucional a "crimencito". (F. P. Arboleda, Ed.) Cuadernos de Derecho Penal, 2.

Muñoz Conde, F. (2001). Introducción al Derecho penal. Montevideo: B de F.

Muñoz Conde, F., \& Garcia Arán , M. (2012). Derecho Penal. Parte General. Valencia: Tirant lo Blanch.

Pérez Correa, C. et al. (2012). Justicia desmedida: Proporcionalidad y delitos de drogas en America Latina. México: Editorial Fontamara.

Pérez Pinzón, Á. O. (2000). Un siglo de jurisprudencia penal. Bogotá: Ediciones Librería del Profesional. 
Proyecto de reforma del Código Penal, de Procedimiento Penal y Penitenciario. Bogotá: Publicabeca.

Ramírez Bastidas, Y. (1985). Los estupefacientes. Empresa de publicaciones del Huila.

Ramírez González, R. (1983). La victimología. Bogotá: Temis.

Roxin, C. (1981). Iniciación al Derecho Penal de hoy. Sevilla: Universidad de Sevilla.

Roxin, C. (1997). Derecho Penal Parte General. Madrid: Civitas.

Sentencia C-221 (1994, mayo 5). Demanda de Inconstitucionalidad. M.P. Carlos Gaviria Díaz. Corte Constitucional.

Sentencia C- 574 (2011, enero 12). Demanda de Inconstitucionalidad. M.P. Juan Carlos Henao Pérez. Corte Constitucional.

Sentencia C-882 (2011, noviembre 23). Demanda de Inconstitucionalidad. M.P. Jorge Ignacio Pretelt Chaljub. Corte Constitucional.

Sentencia C-491 (2012, junio 28). Demanda de Inconstitucionalidad. M.P. Luis Ernesto Vargas Silva. Corte Constitucional.

Sentencia (1976, marzo 21). C.P. Alfonso Arango Henao. Sección Primera. Consejo de Estado.

Sentencia (1980, mayo 6). Casación. M.P. Gustavo Gómez Veláquez. Sala de Casación Penal, Corte Suprema de Justicia. Revista Nuevo Foro Penal, 7, 130-139.

Sentencia 29.183 (2008, noviembre de 18). Casación. M.P. José Leonidas Bustos Martínez. Sala de Casación Penal, Corte Suprema de Justicia.

Sentencia 31362 (2009, mayo 13). Casación. M.P. Julio Enrique Socha Salamanca. Sala de Casación Penal, Corte Suprema de Justicia.

Sentencia 31531 (2009, julio 8) Casación. M.P. Yesid Ramírez Bastidas. Sala de Casación Penal, Corte Suprema de Justicia.

Sentencia 28.773 (2010, mayo 25). Casación. M.P. María del Rosario González Muñoz. Sala de Casación Penal, Corte Suprema de Justicia.

Sentencia 38.512 (2012, diciembre 12). Casación. M.P. Gustavo Enrique Malo Fernández. Sala de Casación Penal, Corte Suprema de Justicia.

Sentencia 38.632 (2013, julio de 3). Casación. M.P. José Leonidas Bustos Martínez. Sala de Casación Penal, Corte Suprema de Justicia. 
Sentencia 42.623 (2014, marzo 12). Casación. M.P. Gustavo Enrique Malo Fernández. Sala de Casación Penal, Corte Suprema de Justicia.

Sentencia 33409 (2014, septiembre 3). Casación. M.P. José Leonidas Bustos Martínez. Sala de Casación Penal, Corte Suprema de Justicia.

Silva Sánchez, J. M. (2010). Aproximación al Derecho penal contemporáneo. Montevideo- Buenos Aires: B de F.

Tamayo Medina, C. H. (2008). Delitos de peligro abstracto y antijuridicidad material. Bogotá: Ediciones Jurídicas Gustavo Ibáñez.

Tocora López, F. (1990). Política Criminal en América Latina. Bogotá: Ediciones libreria el profesional.

Uprimny Yepes, R., Guzmán, D. E. \& Parra Norato, J. A. (2013). Penas alucinantes (La desproporción de la penalización de las drogas en Colombia), Bogotá: Dejusticia.

Velásquez Velásquez, F. (1989). Las drogas (Aspectos histórico, sustantivo y procesal). Medellín: Librería Colegas.

Velásquez Velásquez, F. (1990). El porte de insignificante cantidad de droga como delito inocuo. Nuevo Foro Penal, (47) 141-147.

Velásquez Velásquez, F. (2009). Derecho Penal Parte General. Medellín: Comlibros.

Velásquez Velásquez, F. (2014). Manual de Derecho Penal Parte General. Bogotá: Ediciones Jurídicas Andrés Morales.

Welzel, H. (1993). Derecho penal alemán. Santiago: Jurídica de Chile.

Yacobucci, G. (2000). La deslegitimación de la potestad penal. Buenos Aires: Ábaco de Rodolfo.

Zaffaroni, E. (1987). Tratado de Derecho Penal Parte General. Buenos Aires: Ediar.

Zipf, H. (1979). Introducción a la Política Criminal. Madrid: Edersa.

Zugaldía, J. M., \& et al. (2010). Fundamentos de Derecho Penal. Valencia: Tirant lo Blanch. 


\section{IV \\ Reseñas y recensiones}


